\title{
El derecho de acceso a los documentos administrativos: un instrumento esencial para la participación ciudadana. Derecho estatal y local
}

\author{
Miguel Ángel Sendín García \\ Doctor en Derecho. Profesor de Derecho Administrativo
}

Sumario: 1. INTRODUCCIÓN. 2. NATURALEZA JURÍDICA. 3. SUJETOS TITULARES. 4. SUJETOS PASIVOS. 5. CONTENIDO. 6. LÍMITES. 7. MODO DE EJERCICIO. 8. SUPUESTOS ESPECIALES. 9. TUTELA.

\section{INTRODUCCIÓN}

La necesidad de transparencia en la actuación pública es una exigencia irrenunciable en las sociedades modernas ${ }^{1}$, en las que suele considerarse la concurrencia de dicho factor como un elemento consustancial a la democracia ${ }^{2}$. Nuestra Ley de Régimen Jurídico de las Administraciones

\footnotetext{
${ }^{1}$ C. Delpiazzo ha subrayado «como la Sociedad quiere que sea la Administración de principios del siglo XXI: no sólo debe servir sino que debe mostrar cómo sirve, lo cual exige que sea abierta a la información, a la participación y al control democrático, con un funcionamiento transparente que la transforme en una verdadera casa de cristal». «De la publicidad a la transparencia en la gestión administrativa», en Revista de Derecho 3, 2003, p. 115. En la misma línea, F. SAINZ Moreno señala que transparencia «es una de las palabras claves del discurso político actual, como hace pocos años lo fue la de participación, que tanta euforia produjo. No es ciertamente, una idea nueva, como no lo son la mayoría de las que se usan en el lenguaje político y jurídico actual, pero sí es, en este momento, una idea que tiene especial fuerza y se incorpora, incluso simbólicamente, a la arquitectura de los edificios públicos, bóvedas de cristal, cubos de cristal paredes traslúcidas». «Secreto y transparencia», en Estudios para la reforma de la Administración Pública. Director: F. SAINZ MoRENO. INAP. Madrid, 2004, p. 165.
}

${ }^{2}$ Como señala J. Bermejo Vera, el «principio de la transparencia de los asuntos y cuestiones "oficiales" es, como ha sido reiteradamente señalado, consustancial con los regímenes democráticos contemporáneos. Desde un punto de vista sociopolítico, nadie se atrevería, probablemente, a negar las profundas vinculaciones sustantivas que existen entre el principio de publicidad de las decisiones gubernamentales (...) y los propios fundamentos de la democracia, pues es ésta una forma de gobierno que excluye, por principio, la ocultación y el secreto de las medidas y decisiones que se producen para favorecer los intereses generales a que aquélla sirve prioritariamente». «La ocultación y el secreto de los motivos que fundamentan las decisiones, y aun estas mismas, adoptadas por los Poderes públicos se suele juzgar, lejanos los tiempos del predominio de la "razón de Estado" y de los arcana regni, como radicalmente incompatibles con el principio democrático que inspira y adorna la actividad de aquéllos». «El secreto de las Administraciones públicas. Principios básicos y regulaciones específicas del Ordenamiento jurídico español», en Revista Española de Derecho Administrativo 57 (enero-marzo de 1988), p. 17. En el mismo sentido, señala D. OrdóÑEZ Solís que la «necesidad de una Administración más abierta y más transparente es una consecuencia inevitable del proceso de democratización y de participación de los ciudadanos en los asuntos públicos». 
Públicas y Procedimiento Administrativo Común (en adelante LPC) $)^{3}$ ha reconocido expresamente esta necesidad, estableciendo en su art. 3.5 que en «sus relaciones con los ciudadanos las Administraciones públicas actúan de conformidad con los principios de transparencia y participación». En sentido similar, en el ámbito del Derecho Local, el art. 69. 1 de la Ley de Bases de Régimen Local (en adelante LBRL) 4 establece que las «Corporaciones locales facilitarán la más amplia información sobre su actividad y la participación de todos los ciudadanos en la vida local».

Esta obligación de transparencia se concreta en diversas manifestaciones, y tiene una intensidad y un sentido diferente en los procedimientos en los que los administrados tienen la consideración de interesados, y en aquellos en los que carezcan de dicha condición ${ }^{5}$.

En los primeros responde a la necesidad de facilitar que las personas que pueden verse afectadas por la resolución de un procedimiento puedan defender de forma adecuada sus intereses, convirtiéndose, con ello, en una exigencia del principio de contradicción. De lo que se deriva la necesidad de un conocimiento preciso y actual de todas aquellas incidencias que se puedan producir a lo largo del procedimiento. Generando un derecho a recibir información de carácter exhaustivo, pues sólo excepcionalmente se podrá privar al interesado del conocimiento de cualesquiera datos que obren en el procedimiento y tengan incidencia en el mismo; y que tiene que darse con carácter previo a que se dicte la resolución, pues una vez que ya se ha dictado ésta, y haya desaparecido la posibilidad de influir en la misma, pierde en gran parte su sentido. De ahí la especial trascendencia del trámite de audiencia, que permite tomar conocimiento de todos los elementos que obren en el procedimiento y, por tanto, defenderse de ellos, antes de que se dicte la propuesta de resolución.

El planteamiento de la cuestión varía notablemente cuando se trata de exigir esa transparencia respecto a los asuntos en los que no se tiene la

«El derecho de información del ciudadano, la protección de datos personales y la transparencia de la Administración», en Revista del Poder Judicial 73, 2004, p. 60. En opinión de J. A. DomíngueZ LuIs, la «transparencia administrativa constituye hoy en día un elemento consustancial de los sistemas democráticos modernos». «El derecho de información administrativa: información documentada y transparencia administrativa», en Revista Española de Derecho Administrativo 88 (octubrediciembre de 1995), p. 548.

${ }^{3}$ Ley 30/1992, de 26 de noviembre, de Régimen Jurídico de las Administraciones Públicas y del Procedimiento Administrativo Común.

${ }^{4}$ Ley 7/1985, de 2 de abril, Bases de Régimen Local.

5 Parada VÁquez, R.: Derecho administrativo I. Undécima edición. Marcial Pons, 1999, p. 229. 
condición de interesado. Pues en este ámbito la citada obligación asume una doble funcionalidad.

Por un lado, al igual que en el caso anterior, constituye una vía para facilitar la defensa por parte del administrado de sus intereses particulares. A nadie se le escapa que, en ocasiones, la defensa de una posición propia se puede ver notablemente beneficiada por el acceso a datos ajenos al propio procedimiento en que se está inmerso. El caso más claro sería la toma de conocimiento de un asunto similar que puede actuar como un precedente administrativo.

Pero también, por otro lado, sirve a una finalidad muy diferente, la de facilitar la participación del administrado y el control de la Administración por parte de éste. Lo que supone entrar en un terreno ya muy diferente, pues hemos abandonado el espectro del interés egoísta del ciudadano, para entrar en el ámbito del servicio al interés común.

Lo dicho hasta el momento es literalmente trasladable a un elemento clave para lograr ese objetivo de transparencia, como lo es, sin duda, el acceso a la documentación que esté en poder de la Administración.

En éste ámbito se puede distinguir, igualmente, una exigencia de transparencia respecto al interesado en un concreto procedimiento, que se traduce en la necesidad de permitir un conocimiento detallado y exacto de la documentación que obre en el expediente, previamente a que se dicte la resolución que ha de resolver ese asunto. Derecho que opera durante todo el procedimiento administrativo (art. 35. a LPC y art. 84 LPC; en el ámbito local, art. 180 y 168 Reglamento de Organización, Funcionamiento y Régimen Jurídico de las Entidades Locales en adelante ROF) ${ }^{6}$.

Y, por otro lado, una necesidad de transparencia respecto a los no interesados, que se traduce en el derecho de acceso a los archivos y registros, objeto de nuestro estudio, que, al igual que la obligación general de transparencia, sirve a una doble finalidad.

Por un lado, es un instrumento del que puede hacer uso el administrado para obtener información que le facilite la defensa de sus propios intereses. Por otro, y sobre todo, es una poderosa arma para potenciar la intervención del ciudadano en la vida pública. Pues da satisfacción a la necesidad de que los administrados puedan tomar conocimiento de la actuación de la Administración, elemento imprescindible, tanto para la partici6 Real Decreto 2568/1986, de 28 de noviembre, Reglamento de Organización, Funcionamiento y
Régimen Jurídico de las Entidades Locales. 
pación ciudadana ${ }^{7}$, lo que lo vincula a la cláusula de Estado Democráti$\mathrm{co}^{8}$; como para permitir el control social de la Administración ${ }^{9}$, lo que lo conecta con la cláusula de Estado de Derecho ${ }^{10}$.

Es ésta última función la que dota de una posición específica al derecho que nos ocupa, determinando que asuma una especial relevancia. Pues hace que trascienda el interés particular de los ciudadanos, y que se convierta en un instrumento al servicio del interés público. En otras palabras, es algo más que una simple facultad de los sujetos privados, en cuanto va a condicionar una correcta articulación del desarrollo de la acción pública, convirtiéndose con ello en un elemento estructural de todo Estado que se precie de ser democrático.

De este modo, el derecho de acceso a los archivos y registros implica, obviamente, el reconocimiento de un derecho subjetivo a los ciudadanos ${ }^{11}$, como ratifica la propia LPC, que incluye el acceso a los archivos y

\footnotetext{
${ }^{7}$ Señala L.A. Pomed SÁchez que resulta «hoy en día lugar común proclamar el carácter fundamentalmente instrumental del derecho a la información, en especial en el campo de la documentación pública, tendiéndose a considerar como fin cualificado para el ejercicio del mismo su interrelación con el derecho a la participación, así como para el desarrollo de la actitud crítica de la colectividad que se derivaría de una correcta comprensión de lo que supone la libertad de expresión». El derecho de acceso de los ciudadanos a los archivos y registros administrativos. INAP. Madrid, 1989, p. 96. En el mismo sentido, J.M. GuTIÉRRez Delgado considera que «el acceso a los archivos y registros públicos implica una potestad de participación del ciudadano y facilita el ejercicio de la crítica del poder». Régimen Jurídico de las Administraciones Públicas y Procedimiento Administrativo. Aranzadi. Segunda edición. Navarra, 2002, p. 237. También, AlvÁREz Rico, M.; y AlvÁREZ RICO, I.: «Derecho de acceso a los archivos y registros administrativos en la nueva Ley de Régimen Jurídico de las Administraciones Públicas y del Procedimiento Administrativo Común», en Revista de Administración Pública 135, 1994, p. 475. SÁez Lorenzo, M.C.: El derecho de acceso de los ciudadanos a los documentos administrativos. Madrid, 1982, pp. 8-9.
}

${ }^{8}$ Señala el Tribunal Supremo que dicho derecho refleja «una concepción de la información que obra en manos del poder público acorde con los principios inherentes al Estado democrático (en cuanto el acceso a los archivos y registros públicos implica una potestad de participación del ciudadano y facilita el ejercicio de la crítica del poder)». STS de 30 de marzo de 1999. RCJ 1999-3246. FJ. 3.

${ }^{9}$ Considera GutiérRez Delgado que «dicho acceso constituye un procedimiento indirecto de fiscalizar la sumisión de la Administración a la ley y de permitir con más eficacia el control de su actuación por la jurisdicción contencioso-administrativa». Régimen Jurídico de..., p. 237. En la misma línea, Alvaréz Rico; y AlvÁRez Rico: Derecho de acceso..., p. 475. Mestre Delgado, J.F.: El derecho de acceso a archivos y registros administrativos. Civitas. Madrid, 1993, pp. 27-29.

${ }^{10}$ Señala el Tribunal Supremo que dicho derecho refleja «una concepción de la información que obra en manos del poder público acorde con los principios inherentes al Estado (...) de derecho (en cuanto dicho acceso constituye un procedimiento indirecto de fiscalizar la sumisión de la Administración a la ley y de permitir con más eficacia el control de su actuación por la jurisdicción contencioso-administrativa)». STS de 30 de marzo de 1999. RCJ 1999-3246. FJ. 3.

${ }^{11}$ Embrid Irujo, A., en La nueva ley de Régimen Jurídico de las Administraciones Públicas y del Procedimiento Administrativo Común. Coordinadores: M. Sánchez Morón y J. Leguina Villa. Tec- 
registros dentro del catalogo de derechos subjetivos que se reconocen a los ciudadanos en sus relaciones con las Administraciones Públicas (concretamente en la letra $\mathrm{h}$ de su art. 35).

Pero con esto no queda agotada su naturaleza, pues constituye también, al mismo tiempo, un principio objetivo del comportamiento de la Administración: la sujeción de la actividad de la Administración al principio de publicidad $^{12}$, que indirectamente estimula su eficacia y corrección, en cuanto queda sometida en mayor medida al control social ${ }^{13}$.

No es extraño, por ello, que el instrumento normativo llamado a convertir nuestro país en una democracia avanzada, la Constitución de 1978, quisiese dejar un hueco en su texto a esta trascendental institución ${ }^{14}$. Dando lugar a la mención contenida en el art. 105 de nuestra Norma Máxima, que establece que la ley regulará el «acceso de los ciudadanos a los archivos y registro administrativos, salvo en lo que afecte a la seguridad y defensa del Estado, la averiguación de los delitos y la intimidad de las personas».

Este reconocimiento constitucional no ha dejado de ser cuestionado, sin embargo, por una parte de la doctrina, que en su momento consideró que se trataba de una cuestión que carecía de relevancia constitucional ${ }^{15}$. Opinión que, a nuestro juicio, el tiempo se ha encargado de desmentir, dando la razón a quiénes desde un primer momento supieron comprender la gran relevancia de dicha norma ${ }^{16}$, pues el acceso a la documenta-

nos. Madrid, 1993, p. 101. Como señala GutiÉRRez Delgado, «aunque dicho precepto no contenga el término "derecho", la referencia a los ciudadanos supone, indudablemente, el reconocimiento y atribución a aquéllos de un derecho subjetivo al acceso a los archivos y registros administrativos». Régimen Jurídico de..., p. 237.

12 Pomed SÁchez, L.: «El acceso a los archivos administrativos: el marco jurídico y la practica administrativa», en Revista de Administración Pública 142, enero-abril de 1997, p. 445. EMBRID Irujo, en La nueva ley de..., p. 101. KonNickX Frasquet, A., en la obra colectiva Comentarios a la Ley Básica de Régimen Local. Coordinador: M. J. Domingo Zaballos. Civitas. Madrid, 2003, p. 1210. Como señala GuTIÉRREZ Delgado, el derecho de acceso a archivos y registros «constituye un principio objetivo - publicidad de la actuación administrativa que, junto con otros, confirma la imagen constitucional de la Administración Pública». Régimen Jurídico de..., p. 237.

13 SÁnCHEZ Morón, M.: «El derecho de acceso a la información en materia de medio ambiente», en Revista de Administración Pública 137, mayo-agosto de 1995, p. 34.

${ }^{14}$ Como señala Domínguez, Luis, con la Constitución Española puede «hablarse sin ambagages de una apuesta, decididamente, por la solución "aperturista" en el ámbito de la Administración pública, esto es, se proclama con rotundidad el libre acceso a las fuentes de información administrativa». El derecho a la información..., p. 558.

15 AlZaga, O.: La Constitución española de 1978. Ediciones del Foro. Madrid, 1978, p. 651.

${ }^{16}$ Así, R. PARAda VÁzquez, que considera que la «justificación política de estos principios (...) se encuentra en la evidencia de que el poder de las administraciones públicas de dictar reglamentos y 
ción administrativa ha demostrado ser un elemento esencial en todo Estado democrático.

Es, por ello, verdaderamente preocupante, la regulación de la que ha sido objeto este derecho a nivel ordinario. Nuestro Legislador ha asumido tarde y mal el reto de desarrollar el art. $105 \mathrm{CE}$. Hubo que esperar hasta la promulgación de la ley 30/92 para encontrar una regulación general del mismo, pues con anterioridad tan sólo se dictaron normas que se enfrentaron a la tarea de normar ese derecho en ámbitos sectoriales concretos, como el Patrimonio Histórico. Afirmación que es válida también para el Derecho local, pues aunque la LBRL acogió este derecho, lo hizo limitándose a remitir a la futura legislación de desarrollo del art. $105 \mathrm{CE}$.

Tan larga espera no sirvió para que se diera una solución satisfactoria al problema del acceso a la documentación administrativa. Pues, como tendremos ocasión de comprobar a lo largo de este estudio, la regulación que la LPC realiza de esta materia es sumamente deficiente.

Se puede afirmar, sin ningún tipo de exageración, que constituye una de las grandes carencias de nuestro sistema jurídico. Deficiencia que sumada a la más que preocupante descoordinación y falta de rigor de nuestro Derecho documental ${ }^{17}$, dibujan un panorama descorazonador que requiere una profunda revisión.

actos administrativos no comportan funciones banales, sino instrumentos de una extraordinaria potencia (...). A poderes, pues, sustancialmente análogos al poder legislativo y judicial deben corresponder análogas garantías y exigencias procedimentales. Estas garantías estaban ya presentes en nuestro ordenamiento jurídico; sólo faltaba constitucionalizarlas. Su trascendencia para reforzar los mecanismos del Estado de Derecho justificaba sobradamente la elevación de rango». En Comentarios a las Leyes Politicas. Dirigidos por O. Alzaga Villaamil. Tomo VIII. EDERSA, 1985, pp. 300-301. También M. ALVÁREZ RICO, que da «una valoración positiva de la inclusión en nuestra Constitución, elevándola al máximo rango legal, del derecho de acceso a los archivos y registros administrativos». «El derecho de acceso a los documentos administrativos», en Documentación Administrativa 183, 1979, p. 105. La doctrina posterior ha resaltado también la importancia de este reconocimiento. Así, CRUZ MundET, J. R.; y Mikelarena PeÑa, F.: Información y documentación administrativa. Tecnos. Madrid, 1998, p. 317.

17 Esta carencia fue denunciada hace ya tiempo por A. SÁNCHEZ BlANCO, que destacó «la incompatibilidad con los nuevos postulados institucionales de la Constitución de 1978, donde las Instituciones centrales del Estado tienen pendiente de precisar esa importante faceta de las Bases de las Administraciones Públicas que son los archivos, que ya no admiten la unilateral perspectiva de su vinculación histórica a la simple conservación de fondos documentales del pasado, sino que requieren particularizar precisos criterios de procedimiento en la tramitación de la documentación pública en garantía de los ciudadanos, en garantía de las relaciones institucionales, que constituyen la esencia de un Estado descentralizado, en garantía del buen orden en la tramitación de los asuntos públicos, la verificación de la adecuación de las actuaciones administrativas al principio de legalidad y la satisfacción de los intereses generales, que requieren de la adecuada tramitación y tutela de los expedientes administrativos, para hacer factible su adecuado control jurisdiccional o parlamentario, sin olvidar el fehaciente testimonio documental que las instituciones públicas tiene obligación 
En realidad, para que el derecho de acceso tenga una operatividad real y adecuada, no basta con una simple mejora de la errónea regulación del mismo que vamos a estudiar, sino que se hace preciso, además, una transformación radical del proceder administrativo, que le haga más acorde con las exigencias del principio de transparencia ${ }^{18}$. Lo que exige, entre otras cosas, reforzar y clarificar la obligación de documentar suficientemente e incorporar a los archivos la información documentada que sea de interés público ${ }^{19}$.

A ello se debe añadir un aspecto, que por tener un carácter puramente fáctico no deja de ser decisivo, como lo es el de articular las infraestructuras adecuadas para que se pueda hacer efectivo el derecho de acceso ${ }^{20}$. Pues no se puede privar al ciudadano del disfrute de esa facultad por la inexistencia de medios suficientes en la Administración ${ }^{21}$. Siendo conveniente tener presente que su reconocimiento no supone tan sólo admitir una cierta tolerancia respecto a la curiosidad del administrado, sino que impone a los poderes públicos una auténtica labor de prestación a los ciudadanos, que debe dar lugar a la creación de un servicio público que permita su real implantación práctica ${ }^{22}$. De todo ello trataremos de dar cuenta en este estudio, que emprendemos sin más preámbulo.

\section{NATURALEZA JURÍDICA}

Ya sabemos que el derecho objeto de nuestro estudio tiene relevancia constitucional, en cuanto cuenta con un reconocimiento expreso en nues-

de legar». «El sistema de archivos: de las referencias histórico-culturales a las bases de las Administraciones públicas», en Revista Española de Derecho Administrativo 67 (julio-septiembre de 1990), pp. 361-362. Permaneciendo hoy en día en buena medida vigente, a pesar de los avances que se han producido desde entonces. Pues la conservación y acceso a los documentos está abandonada a una normativa descoordinada y dispersa, que difícilmente puede calificarse, sino en tono irónico, como un sistema de archivos.

18 Como señala J. R. Chaves GARCíA, para que el derecho de acceso sea verdaderamente eficaz, «es imprescindible que el actuar administrativo se distancie del funcionamiento tradicional y se acerque a otro más acorde con la transparencia administrativa». «La información ciudadana y el acceso a los registros y archivos de las Administraciones públicas», en Revista de Estudios Locales (CUNAL), $n .^{\circ}$ extraordinario, julio de 2002, p. 171.

19 SAinz Moreno: Prologo, al libro de S. Fernández Ramos: El derecho de acceso a los documentos administrativos. Marcial Pons. Madrid, 1997, p. 18.

${ }^{20}$ SÁnchez Blanco, A.: «Los derechos ciudadanos en la Ley de Administraciones Públicas», en Revista de Administración Pública 132 (septiembre-diciembre de 1993), p. 52.

21 Konnickx Frasquet, en La Ley Básica de..., p. 1231.

22 Alonso IbañÉz, M.R.: El patrimonio histórico. Destino público y valor cultural. Civitas. Madrid, 1992, pp. 175-179. 
tra Norma Máxima. La ubicación de esa consagración constitucional lo sitúa, sin embargo, al margen de los derechos fundamentales, en cuanto se menciona el mismo en el art. $105 \mathrm{CE}$, situado en el Título IV de nuestra Norma Fundamental, muy lejos del Título I, encargado de regular los derechos fundamentales y libertades públicas. Lo que ha motivado que la mayor parte de la doctrina le niegue el carácter de derecho fundamental ${ }^{23}$, y lo considere un simple derecho subjetivo o incluso un principio rector de la política social y económica ${ }^{24}$.

La cuestión no es, sin embargo, ni mucho menos pacífica, pues hay un sector doctrinal importante que defiende su carácter de derecho fundamental, en cuanto se encuentra en estrecha relación con determinados derechos fundamentales, por lo que participaría del carácter fundamental propio de éstos ${ }^{25}$.

Conclusión que ha sido rebatida por gran parte de la doctrina, a la que nos sumamos, que, aunque reconocen la existencia de esa vinculación, consideran que ésta no alcanza a dotar a nuestro derecho de carácter fun-

23 Así, para ÁlvarÉz Rico, no se trata de un derecho fundamental, si bien «va a condicionar en un grado elevado el funcionamiento de otros derechos fundamentales reconocidos constitucionalmente». El derecho de acceso..., p. 111. EmBid IruJo, en La nueva ley de..., p. 104. FernándeZ DEL Toro Alonso, J.M.; De Pedro García, C.: «El acceso de los ciudadanos a los archivos», en Boletín de la ANABAD XLIX (1999 3-4), p. 214. KonNICKX Frasquet, en La Ley Básica de..., p. 1210. Bermejo Vera: El secreto de las..., p. 24. VILlanueva Cuevas, A.: «El derecho de acceso a archivos y registros», en Revista Jurídica de Castilla-La Mancha 18, 1993, p. 110.

24 Torreblanca LópeZ, A.: «El archivo como servicio público», en Boletín de la ANABAD L II 2002-3. Pp. 100-101.

${ }^{25}$ En tal sentido J.M. DESANTES GuANTEr, que considera que el «acceso a los archivos y registros administrativos, a pesar de la colocación sistemática del párrafo b) del art. 105, no puede reconducirse a un simple problema o conjunto de problemas administrativos. Es necesario conectarlo con un derecho más amplio: el derecho a la documentación, que constituye una de las vías de realización del derecho a la información». Lo que supone que «hay que aplicar a la documentación también el art. 20 de la Constitución». "Significado jurídico-documental del art. 105 b) de la Constitución», en Estudios en homenaje al profesor Diego Sevilla Andrés. Tomo I. Universidad de Valencia, 1984, pp. 304-313. También S. FERnÁNDEZ RAmos, que considera que el art. 105 CE «significa declarar, de un modo directo, la publicidad de la información contenida en los archivos y registros administrativos, de tal modo que la información plasmada en los documentos en ellos depositados debe ser considerada como información pública y puede ser objeto inmediato de la libertad de informarse, contenida (...) en el derecho a recibir información del art. 20.1 d) CE». El derecho de acceso a los documentos administrativos. Marcial Pons. Madrid, 1997, pp. 350-357. En la misma línea G. FreiXas GutiÉrRez, que considera que el derecho de acceso a archivos y registros es un «derecho fundamental de carácter social, ya que afecta a toda una colectividad, siendo necesario conectar la redacción de este artículo con el apartado 4 del artículo 18 del propio texto constitucional, a pesar de que en la Constitución Española está conexión sea nula». La protección de los datos de carácter personal en el derecho español. Bosch. Barcelona, 2001, p. 43. 


\title{
damental ${ }^{26}$; y por la propia jurisprudencia, pues el Tribunal Supremo ha tomado claramente partido, en algunas de sus sentencias, a favor de los que negamos la cualidad de derecho fundamental al derecho de acceso ${ }^{27}$.
}

Tampoco ha habido uniformidad a la hora de integrar este derecho dentro de la categoría de los derechos de tercera generación, que, como es sabido, son un conjunto de derechos que vendrían a dar respuesta a las nuevas necesidades que la modernidad plantea a los ciudadanos ${ }^{28}$. Pues

\begin{abstract}
${ }^{26}$ Señala Pomed SÁNCHEZ que «el artículo 105. b) ha sido caracterizado las más de las veces como una "disposición satélite" de concretos derechos fundamentales». «Dos han sido los propósitos perseguidos con ello. De una parte, incrementar los cauces, las garantías procesales del derecho de acceso a la documentación administrativa. Sabiendo en todo caso que aquél debe representar un papel subordinado, que se planteará como un argumento a fortiori y sólo en muy contadas ocasiones como el núcleo de la hipotética decisión judicial (...). De otra, abordar el examen del sentido y contenido del art. 105. b) Const. desde la óptica de la unidad sistemática y conceptual del texto constitucional. Desde esta segunda perspectiva las consecuencias son, sin duda, más modestas, pues únicamente se considera al art. 105. b) como "norma adscripta" de derecho fundamental en aquellos supuestos en los que, a la vista del caso concreto, complete la esfera jurídica protegida por el derecho fundamental desde una fundamentación iusfundamental correcta». Lo que en todo caso no convierte «el derecho de acceso a la documentación administrativa en un derecho fundamental». $E l$ acceso a los..., pp. 444-445. EMBID IRUJO señala que «esta conexión profunda no hace que se comunique el carácter fundamental de unos derechos que, evidentemente, lo tienen, al de acceso a archivos y registros. Lo único que sucederá en el plano de la práctica es que, muy probablemente, la articulación procesal de la discusión en torno al acceso a los documentos, se fundamentará sustancialmente, sobre el derecho de participación política o la libertad de expresión para, de ese modo, incrementar las posibilidades de garantía jurisdiccional. De esta forma, el derecho de acceso se configurará en las demandas y en los considerandos de las sentencias, como un elemento auxiliar del proceso y del discurso en general y ese carácter auxiliar puede hacer pensar, en algún momento, en la conexión de naturaleza que pudiera producir el derecho». En La nueva ley de..., p. 105. Considera SÁNCHEZ MoRón que «el derecho de acceso es de configuración legal, que, si bien tiene relación con algunos derechos fundamentales, no se identifica ni se subsume en ellos». El derecho de acceso... p. 38. La misma opinión, Villanueva Cuevas: El derecho de acceso..., p. 110.

27 Así lo ha señalado el Tribunal Supremo, indicando que la Constitución regula este derecho como «derecho no fundamental, aunque relacionado con el derecho de participación política, con el derecho de libertad de información y con el derecho de tutela judicial efectiva». STS de 30 de marzo de 1999. RCJ 1999-3246. FJ. 3. También en STS de 14 de noviembre de 2000. RCJ 2001-425. En la que ha señalado que dicho derecho «se halla en una relación instrumental respecto de determinados derechos fundamentales, aun cuando no goce, en sí, de la protección reforzada de los mismos». FJ. 8.
\end{abstract}

${ }^{28}$ En tal sentido, señala A. I. HERRÁN ORTIZ que «el reconocimiento de los derechos fundamentales adquiere nuevos matices, que responden al incipiente avance social en la totalidad de las áreas de la vida en comunidad. Cuestiones como la calidad de vida, la paz social, el derecho de consumidores y usuarios o la protección de la persona frente a los avances tecnológicos exigen respuestas precisas y satisfactorias del legislador nacional, que ha de considerar la acuciante necesidad de salvaguardar al individuo de las amenazas de la modernidad. Con la mirada puesta en estos avances y como respuesta a la necesaria tutela de derechos humanos, nace la Tercera Generación de Derechos, con el propósito de complementar la protección que el individuo precisa y que los anteriores derechos venían dispensando. Estos nuevos derechos fundamentales, surgen para hacer frente a las necesidades de los individuos propias de la denominada era tecnológica». El derecho a la intimidad en la nueva Ley Orgánica de Protección de Datos Personales. Dykinson. Madrid, 2002, pp. 56-57. J. 
algunos lo han encuadrado dentro de la esta categoría ${ }^{29}$, mientras que otros cuestionan dicha tesis ${ }^{30}$. Si bien la jurisprudencia ha aceptado esta calificación ${ }^{31}$.

No plantea ninguna duda, pues se puede deducir del propio tenor literal del art. $105 \mathrm{CE}$, que se trata de un derecho de configuración legal ${ }^{32}$. Tampoco parece discutible que está sujeto a reserva de ley ordinaria, no orgánica ${ }^{33}$. Opinión que sustentan incluso los que consideran que se trata de un derecho fundamental, en cuanto entienden que el desarrollo legal que prevé el art. $105 \mathrm{CE}$ no es una ley que regule directamente el art. 20 $\mathrm{CE}$, sino un texto legal que regula el ejercicio de una de las manifestaciones de este derecho ${ }^{34}$. En cualquier caso, el Tribunal Constitucional ha disipado cualquier tipo de duda al respecto, pues ha declarado que el art. 105. b CE no reconoce «derechos fundamentales y libertades políticas de los incluidos como amparables en el art. 53. 2 de la Constitución $»^{35}$. Y, como es sabido, sólo el desarrollo de éstos derechos fundamentales está sujeto a reserva de ley orgánica.

El hecho de que sea un derecho de configuración legal, no otorga al Poder Legislativo una total capacidad de disposición para fijar su alcance. Pues su desarrollo legal no puede desfigurar el derecho reconocido en el art. $105 \mathrm{CE}$, dejándolo vacío de contenido y privándolo de su sentido

DE EstebAn y P.J. GonZÁLEZ-TREVIJANO señalan que «la tercera generación agrupa los derechos denominados de solidaridad que se han hecho necesarios a la vista del desarrollo, incluso tecnológico, de nuestra sociedad moderna». Curso de Derecho Constitucional Español I. Madrid, 1992. Pp. 265-266.

29 SÁez LoRenzo: El derecho de acceso de..., p. 37.

30 Así, A. EMBrid Irujo, que considera que esa calificación «no pasa de ser una frase motivada por la relativamente "moderna" regulación de este derecho y, en modo alguno, una predicación de naturaleza jurídica junto con las consiguientes consecuencias». El ciudadano y la Administración. MAP. Madrid, 1994, p. 91, nota 18.

31 STS de 14 de noviembre de 2000. RCJ 2001-425. FJ. 5.

32 Así lo confirma también la jurisprudencia. STS de 30 de marzo de 1999. RCJ 1999-3246. FJ. 3.

33 Garrido Falla, F., en Comentarios a la Constitución. Segunda edición. Civitas. Madrid, 1985. P. 1451. Embid Irujo, en La nueva ley de..,. P. 104. VillanueVA Cuevas: El derecho de acceso..., p. 110. AriÑo Ferrer, E.: «El deber de información de la Administración y el derecho de intimidad», en La Ley 1995-3, p. 772.

34 Fernández Ramos: El derecho de acceso..., p. 449, nota 201. Curiosamente, sin embargo, CRUZ Mundet; Mikelarena Peña han considerado que está sujeto a reserva de ley orgánica, en lo que parece debe ser un error, pues estos autores niegan el carácter de derecho fundamental a este derecho, lo que excluye la posibilidad de que sea regulado por una ley orgánica. Información y documentación..., p. 317.

35 STC 161/1988, de 20 de septiembre de 1988. FJ. 4. 
propio, sino que deberá respetar en todo caso su núcleo o contenido esen$\mathrm{cial}^{36}$.

De tal forma que, como señala el Tribunal Supremo, «en aplicación directa de la norma constitucional, este derecho exige, con el fin de respetar su núcleo esencial integrado por el haz de facultades que lo hacen reconocible y la efectividad de los intereses del administrado a que responde, que se haga en un grado razonable asequible a los particulares, superando las limitaciones derivadas de su posición de inferioridad material frente a los poderes públicos, el adquirir conocimiento de los datos y documentos que puedan legítimamente interesarles, sin otras limitaciones que las que el propio precepto constitucional contempla (...) y las derivadas de las normas generales del procedimiento y de los principios de proporcionalidad, racionalidad y buena fe a que debe sujetarse el ejercicio de todo derecho» ${ }^{37}$.

Dentro del respeto a ese contenido esencial, el legislador puede limitar nuestro derecho, pues, como ha señalado el Tribunal Constitucional, ningún «derecho constitucional es un derecho ilimitado» ${ }^{38}$. Si bien, su naturaleza constitucional debe ser tenida en cuenta a la hora de fijar la legitimidad de los límites que se imponen al mismo.

Para examinar esa cuestión debe partirse de que el art. $105 \mathrm{CE}$ fija tan sólo tres límites al derecho de acceso: «lo que afecte a la seguridad y defensa del Estado, la averiguación de los delitos y la intimidad de las per-

\footnotetext{
${ }^{36}$ En este sentido, señala EMBID IRUJo que no se puede «entregar a la Ley incondicionalmente la regulación del mismo hasta el punto de que pueda afirmarse la posibilidad de que la Ley vaciara, en la realidad, la misma existencia del derecho. Hay un principio general constitucionalmente garantizado que es el de la posibilidad de acceso a los registros y archivos administrativos. Existen, también, unas causas constitucionalmente previstas de exclusión del mismo. Será posible que el ordenamiento jurídico ordinario desarrolle estas causas o añada algunas nuevas que guarden relación de conexión con ellas o que se vinculen a otros valores constitucionales, pero lo que será en todo caso imposible hasta el punto de constituir una violación constitucional (susceptible del correspondiente recurso de inconstitucionalidad) es una regulación ordinaria que venga a olvidar el sentido tan claro y diáfano del art. 105. b) CE». El ciudadano y..., p. 94. En la misma línea, Villanueva Cuevas considera que, «si bien la Constitución Española remite su desarrollo a la ley, ésta no puede regular de manera ilimitada este derecho de forma que pudiera llegar a vaciarse el contenido del derecho mismo». El derecho de acceso..., p. 116. El propio Tribunal Constitucional ha señalado que la idea de contenido esencial «que en el art. 53 de la Constitución se refiere a la totalidad de los derechos fundamentales», "puede referirse a cualesquiera derechos subjetivos sean o no constitucionales». STC 11/1981, de 8 de abril de 1981. FJ. 8. Así como la necesidad de que las limitaciones a las que se sujetan los derechos constitucionales, no rebasen su contenido esencial. STC 11/1981, de 8 de abril de 1981. FJ. 9.

37 STS de 14 de noviembre de 2000. RCJ 2001-425. FJ. 5.

${ }^{38}$ STC 11/1981, de 8 de abril de 1981. FJ. 9.
} 
sonas». Mientras que, como veremos, la legislación ordinaria, al llevar a cabo su desarrollo, establece un amplio catálogo de limitaciones, que superan con mucho las restricciones anteriormente citadas.

Cabe preguntarse, entonces, por la constitucionalidad de las mismas. Para lo que se debe indagar, en primer lugar, si es inconstitucional establecer, respecto a un derecho constitucionalmente reconocido, restricciones diferentes a las que expresa y específicamente recoge la Constitución para el mismo. Cuestión a la que debe darse una respuesta negativa, aunque algún autor haya señalado lo contrario ${ }^{39}$. Pues es doctrina asentada que los derechos contenidos en la Constitución pueden verse sujetos a otras limitaciones ${ }^{40}$.

Debemos determinar, entonces, cuáles son los parámetros a los que está condicionada la legitimidad de esas restricciones.

En primer lugar, el establecimiento de esos límites está sujeto a un condicionamiento de carácter formal, en cuanto tendrán que venir regulados en una norma con rango de ley ${ }^{41}$.

En segundo lugar, es preciso que esos límites, que serán objeto de interpretación restrictiva, se deriven de otros derechos constitucionales o de bienes constitucionalmente protegidos, y que sean proporcionadas a dicho fin, esto es, que sean necesarios y adecuados para salvaguardar ese derecho constitucional o bien constitucionalmente protegido, sin que las restricciones que se deriven para el derecho de acceso puedan ir más allá de lo estrictamente necesario para conseguir ese objetivo ${ }^{42}$.

39 ARIÑO FERRER, que considera que, «aunque la Constitución se remita a las leyes de desarrollo, éstas no pueden introducir limitaciones adicionales». El deber de información... p. 777.

40 Así lo ha establecido el Tribunal Constitucional respecto a los derechos fundamentales, señalando que, «no existen derechos ilimitados. Todo derecho tiene sus límites, que, (...) en relación con los derechos fundamentales, establece la Constitución por sí misma en algunas ocasiones, mientras que en otras el límite deriva de una manera directa o indirecta de tal norma, en cuanto ha de justificarse por la necesidad de proteger o preservar no sólo otros derechos constitucionales, sino también otros bienes constitucionalmente protegidos». STC 2/1982, de 29 de enero. FJ. 5. Dicha doctrina es extensible al derecho de acceso, aunque no constituya un derecho fundamental. En tal sentido, MEsTRE Delgado: El derecho de acceso a..., pp. 123-126. SÁnchez Morón: El derecho de acceso... p. 38. Señala EMBID IRUjo que no hay «inconveniente en aceptar la posibilidad de que la ley regule nuevas cláusulas de exclusión siempre y cuando éstas tengan una justificación objetiva que no conduzca, en sus propios términos, a la negación de la realidad garantizada constitucionalmente». En El ciudadano y la..., p. 119.

41 Fernández Ramos: El derecho de acceso..., pp. 449-451.

42 En cuanto a la necesidad de que esa restricción derive de otros derechos constitucionales o bienes constitucionalmente protegidos, señala el Tribunal Constitucional que todo derecho constitucio- 
Conviene advertir que, para que esa limitación sea proporcionada, no basta cualquier vinculación con el derecho o interés que justifica la excepción, sino que es preciso que su aplicación sea imprescindible para que no se produzca una vulneración efectiva de ese derecho o interés ${ }^{43}$. De lo que se deriva que, si para su protección es suficiente con excluir el acceso tan sólo a una parte de un documento, se debe permitir el acceso parcial, esto es, a la parte del mismo no afectada por la excepción ${ }^{44}$. Siempre, obviamente, que quede asegurado que a partir de los datos a los que se permite el acceso no se va a poder reconstruir la información omitida ${ }^{45}$.

nal tiene sus límites, «que derivan (...) no sólo de su posible conexión con otros derechos constitucionales, sino también con otros bienes constitucionalmente protegidos». STC 11/1981, de 8 de abril de 1981. FJ. 9. Doctrina reiterada constantemente al analizar los límites a los derechos fundamentales. Así, ha señalado que, «sólo ante los límites que la propia Constitución expresamente imponga al definir cada derecho o ante los que de manera inmediata o indirecta de la misma se infieran al resultar justificados por la necesidad de preservar otros derechos constitucionalmente protegidos, pueden ceder los derechos fundamentales». STC 120/1990, de 27 de junio de 1990. FJ. 8. También ha señalado que un derecho fundamental «puede experimentar limitaciones o restricciones en su ejercicio, derivados de su conexión con otros derechos o bienes constitucionalmente protegidos y que habrán de estimarse válidas en tanto no rebasen su contenido esencial, haciéndole impracticable, obstruyéndolo más allá de lo razonable o despojándolo de la necesaria protección». STC 53/1986, de 5 de mayo de 1986. FJ. 2.

Por lo que se refiere a la necesidad de que esas limitaciones sean proporcionadas, señala el Tribunal Constitucional que, «en todo caso, las limitaciones que se establezcan no pueden obstruir el derecho "más allá de lo razonable", de modo que todo acto o resolución que limite derechos fundamentales ha de asegurar que las medidas limitadoras sean "necesarias para conseguir el fin perseguido" y ha de atender a la proporcionalidad entre el sacrificio del derecho y la situación en que se halla aquel a quien se impone». STC 120/1990, de 27 de junio de 1990. FJ. 8.

En cuanto a la necesidad de que estén sujetos a interpretación restrictiva, señala el Tribunal Constitucional que «la fuerza expansiva de todo derecho fundamental restringe (...) el alcance de las normas limitadoras que actúan sobre el mismo; de ahí la exigencia de que los límites de los derechos fundamentales hayan de ser interpretados con criterios restrictivos y en el sentido más favorable, a la eficacia y a la esencia de tales derechos». STC 159/1986, de 12 de febrero de 1986. FJ. 6.

Sobre la aplicación de esta doctrina al derecho de acceso. FeRnÁnDEZ Ramos: El derecho de acceso..., pp. 448-451. Sobre la doctrina general de los límites de los derechos fundamentales puede consultarse: Fernández Segado, F.: El Sistema Constitucional Español. Dykinson. Madrid, 1992. Segunda reimpresión de 1997, pp. 169-172. De Esteban; GonZÁlez-Trevijano: Curso de Derecho..., pp. 275-282.

${ }^{43}$ FERNÁNDEZ RAmos: El derecho de acceso..., p. 453.

${ }^{44}$ FERNÁNDEZ RAMOS: El derecho de acceso..., pp. 454-455. La misma opinión formula en términos negativos D. DE OCAÑA LACAL, que critica que la LPC no contemple expresamente el acceso parcial. «Ignorancia, ilegalidad y otros males: panorámica del derecho de acceso a los archivos públicos en España», en Boletín de la ANABAD XLIX (1999 3-4), p. 178. Así el art. 3.3 de la Orden de 24 de abril de 1997, que regula el acceso al Archivo Central del departamento del Ministerio de la Presidencia (RCL 1997-1057) (en adelante OAACMP), establece que, cuando «los documentos solicitados contengan datos personales que, de acuerdo con la Ley, deban mantenerse reservados, se podrá acceder, no obstante, a la solicitud si se somete a los documentos a procedimientos técnicos que garanticen la omisión de dichos datos en el momento de la consulta».

${ }^{45}$ Así, el art. 3. 3 OAACMP establece que se «cuidará muy especialmente que, a partir de la información suministrada, no sea posible en ningún caso reconstruir los datos personales omitidos». 
El paso del tiempo puede alterar la justificación de estas excepciones, de tal forma que, transcurridos determinados plazos, puede que pierda su sentido la restricción al acceso ${ }^{46}$. Debería, en tales casos, fijarse una limitación temporal para la excepción ${ }^{47}$.

Aunque hoy es una discusión que ha perdido gran parte de su trascendencia, conviene dejar constancia de la polémica doctrinal que se generó, en su momento, acerca de si este derecho constitucional necesitaba o no de desarrollo legal para desplegar su eficacia. Para algunos su aplicabilidad venía ligada a su desarrollo legal ${ }^{48}$, postura que encontró respaldo en alguna jurisprudencia ${ }^{49}$. Si bien la mayor parte de la doctrina, acertadamente en nuestra opinión, se inclinó por la postura contraria, defendiendo que era posible su aplicación, con independencia de que su desarrollo legal se hubiese producido o no ${ }^{50}$. Fue esta última postura, la que acabo finalmente, con alguna vacilación, confirmando la jurisprudencia ${ }^{51}$.

\footnotetext{
46 FeRnández Ramos: El derecho de acceso..., p. 451.

${ }^{47}$ Critica de OCAÑa LACAL que no se haga así en numerosos casos en nuestro ordenamiento jurídi-
} co. Ignorancia, ilegalidad y otros..., p. 177.

48 Así, Alvárez Rico considera que el «derecho a la información administrativa, (...) se conforma constitucionalmente en el art. $105 \mathrm{~b}$ ), pero la exigencia de que habrá de ser estructurado y diseñado por una Ley posterior paraliza la eficacia de este precepto hasta tanto se logre su desarrollo legal primero y reglamentario después. El derecho, por tanto, tiene consagración constitucional, pero sólo se configurará como tal derecho cuando haya aparecido la ley prevista en la propia Constitución». El derecho de acceso..., pp. 109-110.

49 La STS de 16 de octubre de 1979 (RCJ 1979-3369) negó dicha eficacia, señalando que «sin desconocer el superior rango que dentro de la jerarquía normativa tienen los preceptos constitucionales, sin embargo, cuando éstos son declaratorios de principios básicos y la propia norma constitucional expresamente dispone que "una ley regule" el acceso de los ciudadanos a los archivos y registros administrativos, indudablemente se está manifestando, por el propio legislador que para la aplicación de tal principio constitucional se requiere de preceptos complementarios que lo desarrollen y limiten». Cdo. 4.

${ }^{50}$ SÁINZ MoReno, F.: «El acceso de los ciudadanos a los archivos y registros administrativos», en Revista Española de Derecho Administrativo 24, p. 123. FERNÁNDEZ RAMOS: El derecho de acceso..., pp. 356-357. GARCÍA-TREVIJANO GÁRnICA, E.: «Materias clasificadas y control parlamentario», en Revista Española de Derecho Constitucional 48, 1996, p. 147. GutiÉrRez Delgado, en Régimen Jurídico de las..., p. 237. Mestre Delgado señala que no «es posible convenir en que la virtualidad del art. 105 b CE se constriña únicamente a ser una declaración programática de buenas intenciones del constituyente, que carece de efectos hasta que al legislador se le ocurra proceder a desarrollarla». El derecho de acceso a..., p. 62.

51 Pues el Tribunal Supremo ha señalado que, «antes de la promulgación de la norma legal que le da cuerpo, era ya susceptible de desplegar su virtualidad en orden a la adecuada interpretación con arreglo a los preceptos y principios constitucionales de la regulación a la sazón vigente sobre acceso al procedimiento administrativo de los interesados integrada sustancialmente por el art. 62 de la Ley de Procedimiento Administrativo de 1958». STS de 30 de marzo de 1999. RCJ 1999-3246. FJ. 3. La misma doctrina en STS de 14 de noviembre de 2000. RCJ. 2001-425. FJ. 5. 
Como ya habíamos adelantado, el desarrollo legal de este derecho no se llevó a cabo con alcance general hasta 1992, con la promulgación de la LPC, cuyo art. 35. h reconoce que los ciudadanos tienen derecho al «acceso a los registros y archivos de las Administraciones Públicas en los términos previstos en la Constitución y en ésta u otras Leyes». Facultad que regula de forma más detallada en su art. 37.

En el ámbito local aparece regulado en el art. 70. 3 LBRL, que al establecer que todos «los ciudadanos tienen derecho a obtener copias y certificaciones acreditativas de los acuerdos de las corporaciones locales y sus antecedentes, así como a consultar los archivos y registros en los términos que disponga la legislación de desarrollo del art. 105, párrafo b), de la Constitución», renuncia a establecer una normativa sustantiva de este derecho, y se limita a remitir a la regulación estatal que lo desarrolle, que es, como ya dijimos, en la actualidad, la contenida en la LPC ${ }^{52}$. No obstante, tanto en este precepto como en el ROF, se encuentran algunas previsiones específicas al respecto, que serán examinadas al analizar los concretos aspectos a los que se refieren.

Este desarrollo legal, que tanto se hizo esperar, generó una enorme decepción. En verdad la doctrina no ha valorado de modo uniforme nuestra normativa preconstitucional sobre la materia, pues para algunos se optó claramente en ella por la opacidad y el secreto ${ }^{53}$, mientras que otros niegan esta conclusión, considerando que no se daba una situación de

\footnotetext{
52 Como señala F. SOSA WAGNER, el «acceso a archivos y registros no está directamente tratado en la LBRL pues ésta reenvía tal materia a la legislación de desarrollo del art. 105 b) CE y, por tal, debe entenderse hoy el contenido de los art. 37 y 38 LRJ-PAC». Manual de Derecho Local. Aranzadi. Navarra, 2000, p. 167.

53 Así, POMED SÁNCHEZ, que considera que «la Administración española se ha caracterizado tradicionalmente por un fuerte componente de secreto y de oscurantismo, que ha propiciado no pocas filtraciones indiscriminadas, y el nacimiento de esa extraña rama del periodismo amarillo que se denomina rumorología, situación acentuada en aquellas épocas neofeudales en las que el deus ex machina del régimen posee plenos poderes civiles y militares, normativos y ejecutivos, viniendo obligado a rendir cuentas de sus actos única y exclusivamente ante Dios y ante la historia». El derecho de acceso de..., p. 81. También J.M. Desantes GuANTER, que califica la situación anterior al art. $105 \mathrm{CE}$, de «escasos e imperfectos precedentes legislativos». Teoría y Régimen Jurídico de la Documentación. EUDEMA. Madrid, 1987, p. 121. M. MACíA considera también que la «tradición de la Administración Pública es secretista, o, al menos, dificultadora del acceso a la información». «El derecho a la información en el ordenamiento jurídico español», en la obra colectiva Derecho de la información. Ariel. Barcelona, 2003, p. 162. Para SÁEZ LORENZO, «en la lucha entre la publicidad y el secreto, entre la transparencia y la ocultación de información, la Administración ha preferido refugiarse y defenderse en el secreto y la confidencialidad». El derecho de acceso de..., p. 7. SÁnCHEZ Morón destaca que «el arraigo de la "cultura del secreto" en nuestra Administración ha sido (y es) muy profundo». El derecho de acceso..., p. 37.
} 
oscurantismo administrativo ${ }^{54}$. Pero si que existía, en todo caso, el anhelo y la esperanza común de que el art. $105 \mathrm{CE}$ supusiese un avance profundo hacia la transparencia ${ }^{55}$.

Ilusiones que han quedado ampliamente defraudadas, pues como apunta con uniformidad rara veces vista la doctrina, con la nueva regulación contenida en la LPC, poco ha ganado el principio de transparencia, dado el espíritu profundamente restrictivo del derecho de acceso que inspira esta normativa ${ }^{56}$.

\footnotetext{
${ }^{54}$ Para R. PARADa VÁzQuez, el «derecho de acceso de los ciudadanos a los archivos y registros administrativos se proclama y regula en la Ley de Régimen Jurídico y Procedimiento Administrativo Común como si las Administraciones españolas hubieran sido hasta ahora un búnker inaccesible que custodiaran los expedientes administrativos como ricos tesoros celosamente vigilados, jurídicamente protegidos por la regla de un secreto riguroso».- «Sin embargo, esta visión no es conforme con la realidad de la regulación jurídica vigente ni con la práctica administrativa, todo ello mucho más liberal». Por lo que concluye «que, en general no existía con anterioridad a la Ley que comentamos tradición de secretismo alguno en la Administración española». En Régimen Jurídico de las Administraciones Públicas y Procedimiento Administrativo Común. Marcial Pons. Madrid, 1993. pp. 154-155.
}

55 En tal sentido, señala F. GonZÁLEZ NAVARRo que el art. $105 \mathrm{CE}$ «culmina todo un largo trayecto normativo mediante el cual se va produciendo la metamorfosis del principio de secreto en el principio de la transparencia». En la obra escrita conjuntamente con J. González Pérez: Comentarios a la Ley de Régimen Jurídico de las Administraciones Públicas y de Procedimiento Administrativo Común. Civitas. Segunda edición, 1999, p. 1025. En el mismo sentido, señala PoMEd SÁnchez que, «a partir de la aprobación de la Constitución de 1978, el actuar administrativo se producirá a la luz del día, en la plaza pública, o no habrá tal». El derecho de acceso..., p. 95. Para SÁEz LoRENZO, «la mejor garantía de que el cambio habrá de producirse y de que la publicidad de la acción administrativa, que se consagra como principio fundamental, será una realidad que no se verá constreñida por las grandes limitaciones de nuestra legislación preconstitucional, es la inclusión en la Constitución de 1978, en su artículo 105 b) del derecho de acceso de los ciudadanos a los documentos administrativos». El derecho de acceso de..,. p. 8.

56 Señala PARADA VÁzquez que el « legislador, invocando muy diversos pretextos e intereses, como la intimidad de las personas, el interés público, el interés político, etc., ha optado por el secretismo frente a la transparencia. Y es que en el fondo detrás de tanta cautela lo que realmente se percibe es el miedo, un miedo enfermizo, no al conocimiento directo personal por los ciudadanos de los expedientes administrativos, sino un pánico antidemocrático a la actividad investigadora de los medios de comunicación social». Régimen Jurídico de las..., p 157. En la misma línea, M. VAQUER CABALLERÍA califica de «cicatera» la regulación legal del derecho de acceso. «Derechos de los ciudadanos: lenguas de los procedimientos, registros administrativos y subsanación de solicitudes», en Documentación Administrativa 254-255 (1999), p. 91. De forma más matizada, J.A. SANTAMARÍA PASTOR señala que la «nota más sobresaliente de esta regulación se halla en la multiplicidad de cautelas y limitaciones con que se diseñan los requisitos del derecho: cautelas que, a más de abundantes, se hallan redactadas frecuentemente en términos tan ambiguos que su ámbito puede extenderse de manera casi indefinida». Comentario sistemático a la Ley de Régimen Jurídico de las Administraciones Públicas y del Procedimiento Administrativo Común. Editorial Carperi. Madrid, 1993, p. 142. Para PoMED SÁNCHEZ, el art. 37 LPC «contiene un progresivo cercenamiento del derecho de acceso con extremos de dudosa constitucionalidad». El acceso a los archivos..., p. 457. DE OCAÑA LACAL considera que la LPC «ha supuesto en cuanto al derecho de acceso una gran confusión y una interpretación unánimemente calificada de restrictiva con respecto al espíritu del constituyente». 
No obstante, conviene advertir que la crítica a esta deficiente regulación no supone romper una lanza a favor de un acceso ilimitado. Es innegable que este derecho se encuentra ante una difícil encrucijada, pues, los sólidos fundamentos que justifican su reconocimiento, confluyen con todo un conjunto de intereses públicos y privados que pueden verse infringidos si se hace pública determinada información (secreto oficial, intimidad, protección de datos personales, etc.). Esto hace que se trate de una cuestión necesariamente polémica, que entraña un conflicto entre necesidades difíciles de conciliar, pero a su vez inexcusables ${ }^{57}$.

Hay ciertamente algunas voces que defienden que este conflicto debe resolverse tomando partido a favor de la transparencia ${ }^{58}$. Sin quitarles la razón, no queremos dejar de aconsejar prudencia, dado el enorme riesgo que se puede derivar de un acceso excesivo a la información contenida en la documentación administrativa, cuyo potencial es enorme ${ }^{59}$. Pues, en

Ignorancia, ilegalidad y otros..., p. 176. ORDóÑEZ SOLís considera que la regulación de la LPC «más parece preocupada por mantener sus prerrogativas y privilegios frente al ciudadano que por asegurar la máxima apertura y transparencia de la Administración». El derecho de información del..., p. 49.

57 Da Silva OchoA, J.C., en Administraciones Públicas y ciudadanos. Coordinador: B. Pendás García. Editorial Praxis. Barcelona, 1993, pp. 318-319. Como señala SÁInz MoRENo, «el secreto administrativo tiene muy mala prensa (...). El secreto administrativo, o lo que es igual, el secreto del poder, es incompatible con la libertad y hace imposible una real participación ciudadana en los asuntos públicos». «Y, sin embargo, al mismo tiempo que se pide transparencia, se exige a la Administración que guarde riguroso secreto de todo aquello que conoce y cuya difusión externa, o comunicación interna, pueda causar algún perjuicio personal, profesional o económico de los ciudadanos». Secreto e información..., pp. 2863-2864.

58 Así, AlvÁREZ Rico y ALVÁRez Rico, sin «negar que la información implica determinados riesgos, creemos que, con carácter general, son mayores los inconvenientes que origina el secreto y sus dudosas ventajas, siempre que, como es evidente, el derecho a la información no se entienda como un derecho absoluto y se pliegue a unas limitaciones convenientemente diseñadas, como ocurre en las legislaciones más progresivas». Derecho de acceso a los..., p. 476. En la misma línea, FERNÁNDEZ RAMOS considera que «el principio democrático reclama que la publicidad constituya la regla o principio general y la reserva o secreto la excepción al mismo, sólo aceptable en la medida en que constituya instrumento necesario para la protección de intereses constitucionalmente relevantes». El derecho de acceso... p. 447.

${ }^{59}$ Como señala F. SAINZ Moreno, esta «constelación de entes públicos de todas clases que llamamos Administración sabe mucho de ella misma y de nosotros. Un saber difuso, ciertamente detentado por sujetos dispersos, pero hoy acumulable con las redes informáticas y en gran parte incorporado a documentos (...) un conocimiento que es fuente de poder para hacer el bien y para hacer el mal y que, por ello, ha de ser controlado». Prologo, al libro de Fernández Ramos: El derecho de acceso.... p. 13. Esa ingente acumulación de información es, además, inevitable, pues de otro modo, mal podría hacer frente la Administración a las funciones que le son propias en un Estado Social. Como señala J.M. SOUVIRÓn MoRENILLA, «la Administración quizá sólo pueda cumplir los amplios objetivos que le exige el actual Estado Social de Derecho a partir de un detallado conocimiento de las características que las actuales sociedades complejas presentan e incluso de las circunstancias individuales de sus miembros, para así poder dispensar por "proporcionado" un trato igualitario a los ciudadanos y los grupos». «En torno a la juridificación del poder informativo del Estado y el control de datos por la Administración», en Revista Vasca de Administración Pública 40, 1994, p. 123. 
esta materia, tan rechazable es un reconocimiento cicatero del mismo, como uno imprudentemente generoso ${ }^{60}$.

No se puede, verdaderamente, recelar de que la amplitud del acceso, en una legislación tan poco generosa con este derecho como la nuestra, vaya a provocar problema alguno. Pero conviene no perder de vista la necesidad de que una posible reforma de la misma sea equilibrada, para que no se produzca ese efecto, tan frecuente entre los españoles, de no llegar o pasarse.

Con todo, conviene también aclarar que el carácter restrictivo de esta regulación es tan sólo uno más de los problemas que aquejan a nuestro ordenamiento jurídico en este ámbito. En realidad, la normación contenida en el art. 37 LPC sufre bastante más dolencias que ésta: es una normativa excesivamente escasa ${ }^{61}$, además de francamente criticable en prácticamente todos sus extremos, pues dicho precepto cuenta con una sistemática, farragosa y confusa ${ }^{62}$, una clara falta de rigor conceptual ${ }^{63}$ y adolece de una gran imprecisión terminológica ${ }^{64}$. A lo que se añade que no prevé un procedimiento o garantía específica para el ejercicio de este derecho ${ }^{65}$.

Todo ello, en conjunto, configura un derecho de perfiles borrosos e imprecisos ${ }^{66}$. Lo que provoca la existencia de grandes divergencias en su

\footnotetext{
60 En tal sentido, Alzaga advierte de los peligros que puede conllevar un reconocimiento excesivamente amplio del mismo, señalando que «puede prestarse no ya a colas interminables de curiosos desocupados, sino, lo que es mucho más grave, a introducir las pugnas políticas y las maniobras partidarias en los despachos de trabajo de los diversos organismos de nuestra Administración pública». La Constitución española..., p. 651. En la misma línea GARRIDO FALlA, según el cuál, «se ha de advertir que no es éste uno de esos temas que puedan resolverse frívolamente. Téngase en cuenta que, incluso en cuestiones no secretas, la reserva profesional es la que garantiza la imparcialidad que debe exigirse a los funcionarios al redactar sus informes y propuestas. Está claro que desde el instante mismo en que exista el peligro de que un informe sobre educación, sanidad o economía pueda ser conocido y publicado al día siguiente en la prensa, el funcionario escribirá pensando en el "público", no en el "interés público"... que no es lo mismo». En Comentarios a la..., pp. 1453-1454.

61 Konnickx Frasquet, en La Ley Básica de..., p. 1211.

62 Da Silva OchoA, que señala que «la ordenación legal de las materias no podría ser más insatisfactoria. Dejando de lado el contenido de los dos últimos apartados (...), a pesar de lo discutible que resulta su vinculación con el resto del precepto, resulta incomprensible la separación que se opera entre los apartados segundo y tercero, por un lado, y cuarto, quinto y sexto por otro. En Administraciones Públicas y..., p. 320.

63 Álvarez Rico y Álvarez Rico: Derecho de acceso a los..., p. 488.

64 Fernández Ramos: El derecho de acceso..., p. 377. KonNicKX Frasquet, en La Ley Básica de..., p. 1211.

65 Fernández Ramos: El derecho de acceso..., p. 378.

66 Sosa Wagner, F.: Manual de Derecho Local. Tercera edición. Tecnos. Madrid, 1996, p. 134.
} 
aplicación, pues, en muchos casos, que se permita o no el acceso a unos mismos documentos, depende simplemente del criterio adoptado por cada Administración ${ }^{67}$. A lo que se añade que, en ocasiones, conduce a los funcionarios a negar el acceso ante el miedo de incurrir en responsabilidad ${ }^{68}$.

La regulación del acceso a archivos y registros contenida en el art. 37 LPC tiene el carácter de legislación básica al amparo del art. 149. 1.18 CE. Fijando, por ello, un nivel mínimo de protección del derecho de acceso, que debe ser respetado por el legislador autonómico, por las leyes administrativas especiales, y por la normativa local ${ }^{69}$. Si bien, nada impide que las Comunidades Autónomas tengan capacidad para desarrollar ese marco básico, siempre que respeten el mismo ${ }^{70}$; ni que las Entidades Locales puedan dictar sus propias normas en la materia, siempre, lógicamente, que actúen dentro del respeto a ese marco básico y a las normas superiores que le sean aplicables ${ }^{71}$.

Nada impide que en ese desarrollo se flexibilicen los requisitos a los que se sujeta el ejercicio del derecho, pues la LPC, en cuanto norma básica, fija unas garantías mínimas que se deben ofrecer a todos los ciudadanos, pero no impide la ampliación de esas garantías ${ }^{72}$.

Ahora bien, debe tenerse presente, respecto a esta cuestión, que en el campo del derecho de acceso la mayor parte de las limitaciones provienen de la garantía de otros derechos y bienes constitucionalmente protegidos, por lo que la flexibilización de esos requisitos no sería posible, pues estaría ampliando las garantías de determinados ciudadanos, pero reduciendo la de otros. Por ello, en nuestra opinión, estaríamos no ante un desarrollo de ese marco básico, sino ante una vulneración del mismo.

A nuestro juicio esa ampliación es posible sólo cuando no implica limitación de derechos de los administrados. Así, flexibilizar las limitaciones que se imponen al derecho de acceso para proteger la intimidad no sería legítimo, porque no estaríamos ante un incremento de garantías, sino dando una mayor amplitud a un derecho en limitación de otro; sin embar-

\footnotetext{
${ }^{67}$ Konnickx Frasquet, en La Ley Básica de..., p. 1212.

68 Sainz Moreno: Secreto y... Págs. 176-177. Embid Irujo: El ciudadano y..., p. 126.

69 FERnÁndez Ramos: El derecho de acceso..., p. 382. GARCÉs SANAGUSTín, A., en Derecho administrativo especial. Director: J. Bermejo Vera. Civitas. Quinta edición. Madrid, 2001, p. 291.

70 EMBID IRUJo: El ciudadano y..., pp. 127-128.

71 FERnÁNDEZ RAmos: El derecho de acceso..., pp. 372-373.

72 FeRnÁndez Ramos: El derecho de acceso..., pp. 371-372.
} 
go, si se flexibiliza el requisito de petición individualizada de los documentos, estaríamos ante una legítima ampliación de las facultades que ofrece ese marco básico.

\section{SUJETOS TITULARES}

El art. $105 \mathrm{CE}$ atribuye este derecho a los ciudadanos, lo que ha generado una cierta discusión doctrinal. Pues, para algunos, el término ciudadano es utilizado en su sentido más tradicional, refiriéndose tan sólo a los nacionales españoles, lo que priva de la titularidad de este derecho a los extranjeros ${ }^{73}$.

No es esa, sin embargo, nuestra opinión. Es cierto que tradicionalmente se ha utilizado el término administrado para referirse a todo sujeto que queda bajo la acción de la Administración, sea nacional o no; y el término ciudadano para referirse al titular de derechos políticos, por lo que venía referido sólo a los propios nacionales. En los últimos tiempos se ha impuesto la utilización del término, políticamente correcto, de ciudadano, con el mismo significado que se ha dado tradicionalmente al término administrado, parece que con la finalidad de evitar la idea de subordinación que este último término lleva en cierto modo implícita. Es esto lo que explica, a nuestro juicio, la utilización del mismo en la regulación del derecho de acceso, y no un propósito de excluir a los no nacionales de la titularidad de este derecho, que se debe considerar también atribuido, por tanto, a los extranjeros ${ }^{74}$.

\footnotetext{
73 «Consecuente resulta, en efecto, la mención expresa a los ciudadanos en tanto en cuanto el referido derecho de acceso a la documentación administrativa se entienda derivación de un más amplio derecho a la participación, en la medida en que el mismo se estime expresión concreta del status activae civitatis. Siendo así que, según se deduce del art. 23. 1 de nuestra Norma Suprema, deben ser considerados ciudadanos quienes gocen de plenos derechos a participar en los asuntos públicos, especificando a tal efecto el art. 13. $1 \mathrm{CE}$ que, en principio y a salvo lo que pueda disponerse en régimen de reciprocidad para el ámbito local, solamente los españoles serán titulares de los derechos reconocidos en el art. 23. 1. De lo que se infiere, derechamente, que en el ordenamiento jurídico español tendrán la consideración de ciudadanos aquellas personas físicas a quienes se refieren la totalidad de los derechos fundamentales reconocidos en la Constitución y muy particularmente los derechos políticos contenidos en su texto». Pomed SÁNCHEZ: El derecho de acceso de..., pp. 153-154. La misma opinión, CRuz Mundet; Mikelarena Peña: Información y documentación..., pp. 318.

${ }^{74}$ Como ya solicitó en su momento AlváRez Rico, que consideró que «la ley que desarrolle la Constitución en este punto concreto deberá optar por una interpretación lo más generosa posible a la hora de fijar los beneficiarios del derecho; porque lo contrario supondría tanto como privar de él a los extranjeros y personas jurídicas en cuyos respectivos status no existe ningún aspecto que pugne con el reconocimiento del mencionado derecho». El derecho de acceso..., p. 113. La misma postura ha sido defendida con posterioridad por FERNÁNDEZ RAMOS, apoyándose en tres argumentos:
} 
EL DERECHO DE ACCESO A LOS DOCUMENTOS ADMINISTRATIVOS...

Ningún problema debe plantear la atribución de este derecho a las personas jurídicas ${ }^{75}$.

Más problemático ha resultado, sin embargo, determinar si son titulares del mismo también los órganos administrativos. Cuestión que ha generado una cierta polémica doctrinal.

Así, un sector de la doctrina considera, que deberán utilizar la vía de la cooperación entre instituciones públicas ${ }^{76}$, que regula el art. 4 LPC $^{77}$.

Mientras que otro apunta que la colaboración administrativa está sujeta a dos limitaciones (que se trate de materias de la competencia de la Administración pública de que se trate; y que la Administración puede negar la colaboración porque el cumplimiento de ésta pueda causar un perjuicio grave a los intereses cuya tutela tiene encomendada o al cumplimiento de sus funciones), lo que hace necesario, a fin de superar dichas limitaciones, que se considere también como titulares de este derecho a las Administraciones Públicas ${ }^{78}$.

Hay una postura intermedia, más matizada, en la que se distinguen dos supuestos: a) cuando la Administración pretenda ejercitar el derecho de acce-

\begin{abstract}
a) la LPC no utiliza un concepto técnico de ciudadano; b) la vinculación al art. 20. 1 LPC es un derecho a la información que es predicable de todo sujeto; c) no tiene sentido admitir el acceso al expediente durante el procedimiento y luego negárselo una vez terminado. El derecho de acceso... Págs. 391-393. La misma opinión, KONNICKX FraSQUET, en La Ley Básica de..., p. 1215.

75 Como ya solicitó en su momento Álvarez Rico. El derecho de acceso..., p. 113. La misma opinión con posterioridad, EmBid Irujo, en La nueva ley de..., p. 109. Mestre Delgado: El derecho de acceso a..., p. 165. KonNickx FrasQuet, en La Ley Básica de..., p. 1215. Fernández Ramos, que basa esta posición en los mismos argumentos que le llevan a defender la titularidad de los extranjeros. El derecho de acceso..., pp. 391-393. Villanueva Cuevas: El derecho de acceso..., p. 113.

${ }^{76}$ En tal sentido Da Silva OchOA, que considera que los órganos públicos no son titulares, «ya que la cooperación entre instituciones públicas dispone de mecanismos aún más eficaces que el derecho de acceso de los ciudadanos, como por otra parte resulta razonable para cumplir adecuadamente lo previsto en el art. 103. 1 CE». En Administraciones Públicas y..., pp. 322-323.

${ }^{77}$ El art. 4.1 c) LPC establece, al respecto, que las Administraciones Públicas deberán facilitar a las otras Administraciones la información que precisan sobre las actividades que desarrollen en el ejercicio de sus propias competencias. A lo que añade el art. 4. 2 LPC que, a dichos efectos, «las Administraciones públicas podrán solicitar cuantos datos, documentos o medios probatorios se hallen a disposición del ente al que se dirija la solicitud». La «asistencia y cooperación requerida sólo podrá negarse cuando el ente del que se solicita no esté facultado para prestarla, no disponga de medios suficientes para ello o cuando, de hacerlo, causara un perjuicio grave a los intereses cuya tutela tiene encomendada o al cumplimiento de sus propias funciones. La negativa a prestar las funciones se comunicará motivadamente a la Administración solicitante».
\end{abstract}

${ }^{78}$ FeRnÁndeZ Ramos: El derecho de acceso..., pp. 395-398. 
so para propiciar o facilitar sus propias competencias como poder público; b) cuando la pretensión que la Administración quiera ejercitar estuviera en relación con el ejercicio de las competencias de la Administración poseedora de los archivos, frente a la que la Administración solicitante tendría una actuación parecida a la de un particular. En el primer caso, no sería titular del derecho de acceso, pues debería utilizar la vía de la cooperación administrativa; mientras que en el segundo sería titular de dicho derecho ${ }^{79}$.

Nosotros no vemos la necesidad de reconocer el derecho de acceso a las Administraciones públicas. Pues no nos parece preciso buscar cobertura para los supuestos que no quedan cubiertos por la colaboración administrativa. En el primer caso, no logramos ver la justificación de que la Administración deba acceder a información que no es necesaria para el ejercicio de sus competencias. En cuanto al segundo, grave perjuicio para el servicio público, nada se ganaría con el reconocimiento de derecho de acceso, que contempla dicho supuesto también como una excepción, y además en términos aun más restrictivos, pues basta para negar el acceso que se afecte al funcionamiento del servicio (art. 37. 7 LPC), mientras que en el caso del deber de colaboración se exige que se cause un grave perjuicio a los intereses encomendados.

La edad es también un factor que afecta a la titularidad de este derecho, pues éste corresponde, en principio, sólo a los mayores de edad ${ }^{80}$. Si bien debe atribuirse su titularidad también a los menores en los términos del art. $30 \mathrm{LPC}^{81}$.

Para ejercitar este derecho no es necesario ser titular de derechos subjetivos o intereses legítimos en los términos que establece el art. $31 \mathrm{LPC}^{82}$. Si bien en algunos supuestos se establecen reglas particulares de legitimación para determinados expedientes:

\footnotetext{
79 Embid Irujo, en La nueva ley de..., p. 112. Opinión que ha hecho suya, Villanueva Cuevas: El derecho de acceso..., p. 114.

80 Cruz Mundet; Mikelareña PeÑa: Información y documentación..., p. 318.

${ }^{81}$ FeRnÁndez RAmos: El derecho de acceso..., p. 394. Dicho precepto establece que tienen capacidad de obrar «los menores de edad para el ejercicio y defensa de aquellos de sus derechos e intereses cuya actuación esté permitida por el ordenamiento jurídico-administrativo sin la asistencia de la persona que ejerza la patria potestad, tutela o curatela. Se exceptúa el supuesto de los menores incapacitados, cuando la extensión de la incapacitación afecte al ejercicio y defensa de los derechos o intereses de que se trate».

${ }^{82}$ Así lo ha señalado el Tribunal Supremo, que considera que «la vinculación más fuerte de la Constitución impone una noción de interesado más amplia que la que en principio se infiere de la definición del art. 23 de la propia ley (hoy sustituido por el art. 31 de la Ley 30/1992), que vincula el reconocimiento de este carácter a la titularidad de un derecho o a la personación en el procedimiento de los titulares de intereses directos afectados. Dichas limitaciones sólo son aplicables a la noción
} 
a) En el caso de los documentos que contengan datos referentes a la intimidad de las personas, el acceso está reservado a dichas personas (art. 37. 2 LPC).

El concepto de documentos que contengan datos relativos a la intimidad de las personas no es claro. Hay que buscar por tanto criterios que permitan determinar, como señala la jurisprudencia, «si los datos solicitados por el demandante afectan o no a esas facetas tan reservadas de las vidas de las personas que por ello merecen tan especial protección» ${ }^{83}$.

Se ha defendido al respecto una interpretación muy restringida, que incluiría los datos sanitarios, pero no los fiscales, religiosos, relativos a opciones políticas, etc. De tal modo que los «datos referentes a la intimidad personal o familiar son tan reservados, jurídicamente tan protegidos y tan irrelevantes para la actividad administrativa que ni podrán ni serán normalmente objeto de los procedimientos administrativos ${ }^{84}{ }^{84}$.

No nos parece correcta una interpretación tan estricta, pues parece incuestionable la inclusión dentro del ámbito de la intimidad de los datos que tienen el carácter de especialmente protegidos en la Ley Orgánica de Protección de Datos de Carácter Persona ${ }^{85}$, esto es, los que hacen referencia a la ideología, afiliación sindical, religión y creencias, origen racial, salud y la vida sexual ${ }^{86}$. A lo que se deben añadir otros como el estado civil o la filiación ${ }^{87}$.

de interesado referida a un procedimiento en concreto ya iniciado y pendiente de resolución o resuelto por la Administración (...). No lo son al particular que se halla en el trance previo de reunir información necesaria para tomar conocimiento de su situación y derechos frente a los poderes públicos (supuesto que debe hoy remitirse a la regulación separada contenida en el art. 37 de la nueva Ley, en el cual no se exige ya requisito alguno general de orden legitimador para poder obtener información más que ostentar la cualidad de ciudadano». STS de 30 de marzo de 1999. RCJ 1999-3246. FJ. 3. En el mismo sentido, apunta DA SILVA OCHOA que la regla de los art. 105 CE y 37 LPC «no exige nada añadido a la condición de ciudadano». En Administraciones Públicas y..., pp. 322-323. La misma opinión, Gutiérrez Delgado: Régimen Jurídico de..., p. 238. García-TreViJano Garnica: Materias clasificadas y..., p. 148. Álvarez Rico y Álvarez Rico: Derecho de acceso a los..., p. 481.

83 STSJ de Cataluña de 14 de mayo de 1996. RJCA-797 (contencioso-administrativo). FJ. 3.

84 Parada VÁzQuez: Régimen Jurídico de las..., pp. 157-158.

85 Ley Orgánica 15/1999, de 13 de diciembre, de Protección de Datos de Carácter Personal.

${ }^{86}$ Konnickx Frasquet, en La Ley Básica de..., p. 1216. Fernández Ramos: El derecho de acceso..., pp. 489-491. Chaves GARcía: La información ciudadana..., p. 162.

${ }^{87}$ FERnÁndez Ramos: El derecho de acceso..., p. 491. KonNickX Frasquet, en La Ley Básica de..., p. 1216. ChAVES GARCÍA considera también incluido el estado civil en el ámbito de la intimidad. $L a$ información ciudadana..., p. 162. 
Más discutible es el caso del DNI y el domicilio, que algunos autores incluyen en el ámbito de la intimidad ${ }^{88}$, mientras que otros consideran que no forma parte del mismo ${ }^{89}$.

No parece que deban incluirse dentro del ámbito de la intimidad los datos económicos ${ }^{90}$. Extremo que parece confirmar la jurisprudencia, que entiende que no se puede considerar que afecte a la intimidad el acceso a los expedientes de liquidaciones por el impuesto sobre el incremento de valor de los terrenos derivados de transmisiones en los que no se ha sido parte ${ }^{91}$; ni la expedición de certificación acreditativa de la situación de alta de determinados deudores de la entidad recurrente en el Registro de Impuestos sobre Actividades Económicas $^{92}$.

b) El derecho de acceso podrá ser ejercido, además de por sus titulares, por terceros que acrediten un interés legítimo y directo respecto a los documentos de carácter nominativo que sin incluir otros datos pertenecientes a la intimidad de las personas figuren en los procedimientos de aplicación del derecho, salvo los de carácter sancionador o disciplinario, y que, en consideración a su contenido puedan hacerse valer para el ejercicio de los derechos de los ciudadanos (art. 37. 3 LPC).

El análisis de este precepto exige distinguir diversas cuestiones. En primer lugar, se deriva del mismo, mediante una interpretación sensu contrario, una exclusión del acceso de los ciudadanos en general a los documentos derivados de procedimientos sancionadores o disciplinarios ${ }^{93}$. De tal forma que se permitirá el acceso tan sólo al propio inculpado y a los

${ }^{88}$ FernÁNDEZ Ramos: El derecho de acceso..., pp. 491. Chaves García: La información ciudadana..., p. 161.

${ }^{89}$ Konnickx Frasquet, en La Ley Básica de..., p. 1219.

${ }^{90}$ Konnickx Frasquet, en La Ley Básica de..., p. 1218. De forma más matizada FernándeZ RAMOs, que considera que «los datos económicos, por sí mismos, no están protegidos por el derecho a la intimidad, salvo que comporten el acceso a informaciones ya no atinentes a la esfera económica de la persona, sino relativas directamente a su vida íntima personal y familiar». El derecho de acceso..., pp. 497-498.

${ }^{91}$ STSJ de Cataluña de 14 de mayo de 1996. RJCA-797 (contencioso-administrativo). FJ. 3.

${ }_{92}$ Pues tales «datos no pueden entenderse como pertenecientes a la intimidad de las personas, pues no tienen tal carácter la realización de las actividades que grava, cuya finalidad ha de ser la de intervenir en la producción o distribución de bienes o servicios». STSJ de Valencia de 7 de noviembre de 1995. JT-1400. FJ. 1-4.

${ }^{93}$ FERnÁNDEZ RAmos: El derecho de acceso..., pp. 506-507. 
demás interesados ${ }^{94}$. Pero no a los denunciantes que no tengan el carácter de interesados ${ }^{95}$.

Aunque hay quien mantiene opinión contraria ${ }^{96}$, estas limitaciones deben ser valoradas, en nuestra opinión, favorablemente, dada la gravedad de los perjuicios que puede llegar a revestir el conocimiento público de este tipo de datos, que pueden ser tan lesivos como la imposición de una nueva sanción ${ }^{97}$.

En segundo lugar, respecto al resto de los documentos nominativos que no contengan datos relativos a la intimidad de las personas, el artículo 37. 3 LPC, limita el acceso a sus titulares y a terceros que acrediten un interés legítimo y directo.

Este precepto resulta extremadamente impreciso y poco claro. Primero, porque no resulta en absoluto sencillo determinar que es lo que debe entenderse por documento nominativo, lo que obliga a precisar el sentido de dicho término ${ }^{98}$.

Un grupo de autores, tomando base en el Derecho comparado, consideran como tales los documentos que cumplen dos notas: a) contener el nombre de la persona o personas concretas afectadas o ser éstas fácilmente identificables; b) que el contenido del documento realice una apre-

\footnotetext{
${ }^{94}$ Fernandez Ramos: El derecho de acceso..., pp. 508-509. Konnickx Frasquet, en La Ley Básica de..., pp. 1217-1218.

95 FreiXas Gutiérrez: La protección de los..., p. 46. Konnickx Frasquet, en La Ley Básica de..., p. 1217.

96 Según PARAdA VÁzQUEZ, la «razón del secretismo no puede verse en la naturaleza punitiva de los expedientes desde el momento en que los sumarios, los actos penales mismos, dejan de ser secretos a partir del momento en que se levanta el secreto sumarial y con él se produce el acceso de las partes a su contenido, abriéndose así su conocimiento a la opinión pública. Puede caber la sospecha de que con esta limitación no se está protegiendo al sancionado, cuyo interés en el secreto no debe ser superior al interés público de la transparencia informativa, sino más bien defendiendo del conocimiento público actuaciones administrativas poco claras, sobre todo cuando son negligentes o indulgentes con los hechos investigados». Régimen Jurídico de las..., p. 158.
}

97 Ariño FerRer: El deber de información..., p. 783. Según FreiXas GutiérRez, «lo cierto es que el acceso a expedientes sancionadores puede acarrear el conocimiento general de su tramitación y finalización, con la consiguiente publicidad cuando la mayoría de normativas sancionadoras, afortunadamente, intentan limitar a través de establecer la publicidad de las sanciones administrativas como una sanción de carácter accesorio cuando se hayan cometido infracciones graves o muy graves. El acceso a los expedientes sancionadores podría comportar, en mi opinión, sustraer al control de la legalidad una actuación administrativa que sólo se puede imponer ante infracciones y situaciones muy graves». La protección de los..., p. 45.

98 Gónzalez Navarro: Comentarios a la Ley de Régimen..., p. 1027. 
ciación o un juicio de valor sobre conductas o comportamientos de esas personas cuya divulgación puede producir un perjuicio ${ }^{99}$.

Mientras que otros autores entienden que se deben considerar como tales aquellos que contienen datos que permiten la identificación de las personas a los que van referidos ${ }^{100}$.

Es esta segunda opinión la que debe prevalecer, pues, de una interpretación sistemática de la regulación contenida en el art. 37. 3 LPC, resulta evidente que la exclusión contenida en dicha norma viene referida a los documentos en los que aparecen identificadas las personas a las que se refiere, pero que no afectan a su intimidad ${ }^{101}$.

En segundo lugar, es criticable la oscura referencia que se realiza a los procedimientos de aplicación del derecho, pues todo procedimiento en mayor o menor medida aplica normas jurídicas ${ }^{102}$.

No menos distorsionador resulta que se exija un interés legítimo y directo, pues esta noción ha sido siempre muy confusa y de difícil precisión $^{103}$. Algunos autores han sugerido que con ello se quiere excluir de la titularidad de este derecho a los portadores de intereses colectivos o difusos, especialmente a los medios de comunicación social y asociaciones y organizaciones sociales ${ }^{104}$. Sea cual sea la intención del legislador, no nos parece una restricción conforme a la finalidad que inspira el derecho de acceso, por lo que nos sumamos a la posición de los que consideran que debe considerarse que basta con que se ostente simplemente un interés legítimo, sea o no directo ${ }^{105}$.

Por último, tampoco parece que tenga mucho sentido que se exija que sean documentos que, «en consideración a su contenido, puedan hacerse valer para el ejercicio de los derechos de los ciudadanos». En la práctica

\footnotetext{
99 Gutiérrez Delgado: Régimen Jurídico de..., p. 240. Mestre Delgado: El derecho de acceso a..., p. 138. Cruz Mundet; Mikelarena Peña: Información y documentación..., p. 325.

100 Embid Irujo, en El ciudadano y la ..., p. 101. KonNickX Frasquet, en La Ley Básica de..., p. 1222. SÁnCHEZ Morón: El derecho de acceso..., p. 39.

101 Fernández Ramos: El derecho de acceso..., p. 505. De OCAÑa LACAL: Ignorancia, ilegalidady otros..., p. 187 , nota 38 .

102 Konnickx Frasquet, en La Ley Básica de..., pp. 1219-1220. Villanueva CuEvas: El derecho de acceso..., p. 115. ARIÑo FERRER: El deber de información..., p. 777.

103 SÁnchez Morón: El derecho de acceso..., p. 39.

104 SÁnChez Morón: El derecho de acceso..., p. 39.

105 KonNickX Frasquet, en La Ley Básica de..., p. 1221.
} 
será muy difícil comprobar la concurrencia de esta exigencia, pues como mucho se podrá ver si ese administrado ostenta o no un derecho subjetivo o interés legítimo, descartando los supuestos de simple curiosidad ${ }^{106}$.

\section{SUJETOS PASIVOS}

No parece dudoso que son sujeto pasivo de este derecho las Administraciones territoriales ${ }^{107}$. Extendiéndose el derecho de acceso respecto a las mismas a toda su documentación, con independencia del régimen jurídico de su actuación (privado o público) ${ }^{108}$.

No lo es tampoco su extensión a las entidades vinculadas o dependientes de las anteriores, pero si hasta donde alcanza dicha extensión. Pues para algunos sólo rige el derecho de acceso respecto a estas entidades cuando desarrollan funciones administrativas ${ }^{109}$; mientras que otros consideran que su ámbito de aplicación abarca todos sus documentos, independientemente del carácter administrativo o no de las funciones que desarrollen ${ }^{110}$.

Por lo que se refiere a las Corporaciones de derecho público, se tiende a considerar que sólo son sujeto pasivo de este derecho cuando desarrollan funciones administrativas ${ }^{111}$. Si bien algunos autores parecen insinuar

\footnotetext{
106 Señala Chaves García que en «la práctica resultará muy difícil decidir si el contenido de un documento puede ser de utilidad al interesado para el ejercicio de sus derechos, pues, salvo que en su petición nos desvele que derechos pretende ejercitar, carecemos de elementos objetivos para realizar tal valoración. Por ello, salvo los supuestos manifiestos de la mera curiosidad, no encontraremos fundamentos objetivos para denegar el derecho de acceso en base a que los documentos, por su contenido, no son susceptibles de hacerse valer para el ejercicio de los derechos por terceros interesados». La información ciudadana..., p. 164.

107 Mestre Delgado: El derecho de acceso..., p. 100. Fernández Ramos: El derecho de acceso..., p. 404. SÁEz LoRENZO: El derecho de acceso de..., p. 40.

108 Señala FeRnÁndez Ramos que de «lo contrario en todas aquellas actuaciones en las cuales la Administración no tenga ineludiblemente que sujetarse a procedimientos jurídico-públicos quedaría en manos de la propia Administración eludir la aplicación del derecho de acceso, y bien es conocido cuál es el empuje aparentemente imparable de las tendencias privatizadoras. En definitiva el principio de publicidad - como el de objetividad o el de eficacia- preside toda la actuación de las Administraciones públicas». El derecho de acceso..., p. 407.

109 Mestre Delgado: El derecho de acceso a..., p. 103.

110 Fernández Ramos: El derecho de acceso..., p. 405.

${ }^{111}$ Mestre Delgado: El derecho de acceso..., p. 103. De OcAÑa LACAL: Ignorancia, ilegalidad y otros..., p. 198, nota 67. Señala FeRnÁNDEZ RAmos que, «dado que estas corporaciones no "son" Administraciones Públicas, (...) su sometimiento al derecho de acceso no alcanza la totalidad de su actividad, sino tan sólo a aquella faceta de ejercicio de funciones públicas -ya sea por mandato legal
} 
la conveniencia de una mayor extensión ${ }^{112}$. El Tribunal Supremo ha considerado en su jurisprudencia como sujeto pasivo del derecho de acceso a un Colegio de Abogados ${ }^{113}$.

Se considera también que el derecho de acceso es exigible a los concesionarios de servicio público, en cuanto desarrollan las funciones públicas que tengan encomendadas, pero no en cuanto a su posición como sujeto privado $^{114}$. Si bien algunos autores consideran que el hecho de que actúen en el desarrollo de funciones públicas determina tan sólo la obligación de permitir el acceso a esa información, pero sin convertir a los concesionarios en sujetos pasivos del derecho. Posición que corresponderá a la Administración Pública de la que dependan ${ }^{115}$.

No parece que sea aplicable a las empresas públicas ${ }^{116}$. En cuanto a los órganos públicos que no son Administraciones públicas, en la medida en que realizan actividad materialmente administrativa, la doctrina ha considerado que están sujetos a este derecho, pero siéndoles aplicable la LPC sólo de forma supletoria ${ }^{117}$.

\section{CONTENIDO}

Según la LPC dicho contenido consiste en el «derecho a acceder a los registros y a los documentos que, formando parte de un expediente, obren

o delegación de una Administración-, en los que estas organizaciones actúan "en lugar de una Administración", pues de lo contrario quebraría la finalidad de un tratamiento común exigida por la Constitución». El derecho de acceso..., p. 409.

112 Señala EmBid Irujo que las Administraciones Corporativas son sujeto pasivo de este derecho, «al menos, en el ámbito jurídico-público que a ellas compete y que, igualmente, tutelan». En $\mathrm{La}$ nueva ley de..., p. 112.

113 STS de 25 de octubre de 2002. RCJ 2002-10209. FJ. 2.

114 Mestre Delgado: El derecho de acceso..., p. 106.

115 FERnÁndez Ramos: El derecho de acceso..., pp. 413-414.

116 EmBiD Irujo, que considera que su aplicación a las empresas públicas «no tiene sentido si se piensa en los fundamentos mismos de la institución del acceso (derecho ciudadano vinculado al control objetivo de la Administración Pública)». El ciudadano y la...,p. 102.

117 Señala FeRnÁNDEZ RAmos que, «desde la perspectiva del derecho fundamental a recibir información, no cabe duda que los documentos producidos por tales órganos en ejercicio de funciones materialmente administrativas están sujetos al principio de publicidad. Ahora bien, desde la perspectiva de la regulación general del derecho de acceso hay que precisar que la LPAC -dada su función constitucional- únicamente puede entenderse de aplicación supletoria». El derecho de acceso..., p. 415. 
en los archivos administrativos, cualquiera que sea la forma de expresión, gráfica, sonora o en imagen o el tipo de soporte material en que figuren, siempre que tales expedientes correspondan a procedimientos terminados en la fecha de la solicitud» (art. 37. 1 LPC).

No nos parece que dicha determinación sea muy adecuada, por lo que deberemos realizar algunas precisiones, que fijen mejor el contenido de este derecho.

En primer lugar, debe precisarse que otorga una auténtico derecho subjetivo a acceder a la documentación, no una mera posibilidad de solicitar el acceso. Así lo ha ratificado el Tribunal Supremo, que ha dejado sentadas las diferencias entre el derecho de petición y el derecho que nos ocupa, señalando que el «primero de ellos es de carácter mínimo (...) agotándose en la mera posibilidad de ejercitarlo y confiriendo a su titular el derecho de que el escrito de petición sea admitido, se le dé el curso correspondiente y se reexpida en su caso al órgano competente, sin que de ello pueda derivarse perjuicio alguno al peticionario y en el mismo sentido se pronuncia la Jurisprudencia de esta Sala al configurarlo como un derecho "uti cives", sin que en él se incluya el de obtener una respuesta favorable a lo solicitado (...). Por el contrario, el segundo de ellos abarca la facultad de obtener el acceso a la información radicada en los archivos y registros administrativos» ${ }^{118}$.

Ese derecho no puede, además, amputarse bajo el pretexto de falta de adecuación de la información de la que se trate para conseguir la finalidad perseguida por el interesado ${ }^{119}$.

En segundo lugar, debe determinarse cual es el objeto de ese acceso. En la resolución de esta cuestión se plantean algunas dificultades, derivadas de la deficiente terminología que se ha utilizado para calificar este derecho, pues se habla de acceso a archivos y registros, desviando, con ello,

\footnotetext{
118 STS de 23 de junio de 1999. RCJ 1999-4278. FJ. 3.

${ }^{119}$ Como señala el Tribunal Supremo, condicionar el acceso a la concurrencia de los presupuestos que se precisan para lograr la finalidad que pretende el administrado, es tanto como vincular «la posibilidad de obtener la información útil para ponderar las posibilidades jurídicas del ejercicio de una pretensión al parecer administrativo sobre la efectiva titularidad del derecho o interés legítimo hacia el conocimiento de cuyos presupuestos van dirigidas las averiguaciones. Con ello resultaría sacrificada la función instrumental de la información en aras del criterio de fondo de la Administración sobre el objeto a que la misma se refiere y, de este modo, al privar al interesado de los elementos para tomar por sí mismo su decisión y devenir así inútil el derecho de acceso a los archivos y registros públicos (suplantado por el parecer de la Administración sobre la posible utilidad de su resultado) se vulneraría su núcleo esencial, no dependiente de la configuración legal de su ejercicio». STS de 30 de marzo de 1999. RCJ 1999-3246. FJ. 4.
} 
la atención hacia un elemento meramente instrumental (archivos y registros) en perjuicio de su núcleo esencial, que es el derecho a la información ${ }^{120}$.

Esto ha inducido a error a algunos autores, que, tomando como referencia la denominación de que se ha dotado a nuestro derecho, consideran que éste tiene por objeto lo que está comprendido en los archivos y registros administrativos ${ }^{121}$.

Más certera es la opinión de los que, prescindiendo del nombre del derecho, defienden que su verdadero objeto es el acceso a la información contenida en los archivos y registros, pues éstos son simplemente instrumentos para acceder a esa información ${ }^{122}$.

Si bien tampoco esta tesis es, a nuestro juicio, totalmente correcta. Pues, en nuestra opinión, su objeto es, en sentido estricto, el acceso a esa información en cuanto esté documentada. En definitiva, la información que contenga la documentación que esté en poder de la Administración ${ }^{123}$.

Nótese que esto supone que el derecho se puede ejercer no sólo respecto a los documentos que obren en un archivo o registro, como ha entendido algún sector de la doctrina ${ }^{124}$, sino respecto a toda la documentación que posea la Administración, independientemente de que se encuentre o no en un archivo o registro ${ }^{125}$.

\footnotetext{
120 Álvarez Rico y Álvarez Rico: Derecho de acceso..., p. 479.

121 Considera Mestre Delgado que «se reconoce el derecho de acceso a los archivos y registros administrativos, y no se emplea la referencia a la noción "documentos administrativos". Esta circunstancia explica que no resulte tan necesario efectuar una delimitación del contenido de este último concepto, sino de profundizar en la noción de archivos y registros administrativos, que es el concepto relevante en nuestro orden constitucional. De esta forma, todo lo que quede comprendido en tales archivos y registros, salvando las limitaciones constitucionalmente impuestas, será susceptible de ser conocido por los ciudadanos». El derecho de acceso..., p. 117. También parece situarse en esta línea, Villanueva Cuevas: El derecho de acceso..., pp. 116-117.
}

122 Álvarez Rico y Álvarez Rico: Derecho de acceso a los..., p. 484.

123 Fernández Ramos: El derecho de acceso..., p. 418. Pomed SÁnchez: El acceso a los..., p. 461. EmBid Irujo, en La nueva ley de..., pp. 113-114. Señala SÁEz LoRENZO, que «parece que el legislador ha querido recoger los dos vértices del proceso de información administrativa al hablar de registro (lugar donde tienen su ingreso los documentos) y archivo (lugar donde deben quedar depositados éstos), pero precisamente por tratarse del principio y el fin de la vida administrativa de un expediente, debe entenderse que en el derecho de acceso entran todos los documentos que la Administración recibe, genera, conserva y difunde». El derecho de acceso de..., p. 40.

124 Pomed SÁnchez: El derecho de acceso de..., p. 200.

${ }^{125}$ FERnÁndeZ RAmos: El derecho de acceso..., p. 418. 
Tampoco debe impedir el acceso el simple hecho de que los documentos no se hayan insertado en un expediente ${ }^{126}$, pese a que el art. 37.1 reconoce la posibilidad de ejercitar nuestro derecho tan sólo respecto a los documentos que formen «parte de un expediente». Esta restricción no nos parece admisible. En primer lugar, porque la inclusión de los documentos en los expedientes que les correspondan es una obligación de la Administración, cuyo incumplimiento no puede afectar al derecho de los ciudadanos a acceder a los mismos ${ }^{127}$.

En segundo lugar, porque hay documentos que no forman parte de un expediente: a) aquellos que son archivados sin dar lugar a la iniciación de un procedimiento, $\mathrm{y}$, por tanto, no suponen la formación de un expediente; b) la documentación de apoyo informativo elaborada por la Administración $^{128}$.

Hay quien ha considerado que sería legítimo excluir el acceso respecto a las circulares, instrucciones o comunicaciones internas, «ya que son documentos que afectan a la organización interna ajena al fin de transparencia que se persigue con el derecho de acceso» ${ }^{129}$.

No compartimos esta opinión, pues no vemos la razón por la que las instrucciones y órdenes de servicio han de ser secretas. Una cosa es que, en cuanto producen efecto sólo en el ámbito de la organización administrativa, no deban con carácter general ser publicadas, y otra que deban de quedar al margen del principio de transparencia. La propia LPC excluye, a nuestro juicio, dicha interpretación, pues permite incluso su publicación en el diario que corresponda si se considera conveniente o lo exige una disposición (art. 21. 1 LPC). Por ello, en nuestra opinión, deben sujetarse a las mismas reglas que el resto de la documentación, pudiéndose restringir el acceso sólo si hay causa que lo justifique (por ejemplo, porque se vería perjudicada su eficacia).

\footnotetext{
126 SÁnchez Morón: El derecho de acceso..., p. 40. Konnickx Frasquet, en La Ley Básica de..., p. 1212.

127 Pomed SÁnchez: El acceso a los..., p. 462. Señala Da Silva OchoA que la «conservación ordenada de la documentación formando expedientes es una obligación de la Administración, cuyo incumplimiento nunca podrá resultar en perjuicio de un derecho, por ejemplo el de acceso, de un ciudadano. En otras palabras, un ciudadano puede solicitar acceder a un documento que, por negligencia administrativa o cualquier otro motivo, no esté incorporado a un expediente». En Administraciones Públicas y..., p. 326, nota 50.

128 FeRnÁndez RAMOs: El derecho de acceso..., pp. 430-431.

129 Konnickx Frasquet, en La Ley Básica de..., p. 1213.
} 
También es indiferente que esos documentos hayan sido generados o no por la Administración ${ }^{130}$; y que formen o no parte de un procedimiento administrativo ${ }^{131}$. No importa tampoco el tipo de soporte en que estén contenidos, pues el propio art. 37. 1 extiende este derecho a los documentos «cualquiera que sea la forma de expresión, gráfica, sonora o en imagen o el tipo de soporte material en que figuren».

Deben considerarse, igualmente, comprendidos dentro de este derecho, los documentos que aún no estando en poder de la Administración, son de su titularidad. Estando obligada ésta a recuperarlos cuando se demande el acceso a los mismos. Pues, en caso contrario, bastaría a la Administración, para impedir el ejercicio de este derecho, con su remisión a un sujeto privado ${ }^{132}$.

El derecho no se extiende, sin embargo, a la información que obrando en poder de la Administración no esté documentada ${ }^{133}$; ni a los documentos futuros ${ }^{134}$; ni a aquellos que estén en proceso de elaboración pero no han sido acabados (como por ejemplo, un borrador ${ }^{135}$; ni incluye la posibilidad de obligar a la Administración a la elaboración de un documento inexistente ${ }^{136}$.

Lógicamente, el acceso tampoco puede extenderse a los documentos perdidos o destruidos, siempre que se justifique debidamente la destrucción o la búsqueda infructuosa ${ }^{137}$. Si bien deberían establecerse mecanismos efec-

130 Fernández Ramos: El derecho de acceso..., p. 422. SÁez Lorenzo: El derecho de acceso de..., p. 40. KonNickX Frasquet, en La Ley Básica de..., p. 1213.

131 SÁez LoRenzo: El derecho de acceso de..., p. 40.

132 FERnÁndez Ramos: El derecho de acceso..., p. 436.

133 Pomed SÁnchez: El derecho de acceso de..., p. 200. Lo que, en opinión de Fernández Ramos, «supone, de entrada, excluir del derecho de acceso la información "bruta", esto es, la información que no esté materializada o plasmada en un documento, pues la obtención de esa información (...) comporta necesariamente un derecho de estructura prestacional, en el cual el objeto del derecho a falta de documentos no puede ser otro que la actividad de prestación informativa de la Administración». El derecho de acceso..., p. 423.

\footnotetext{
134 Fernández Ramos: El derecho de acceso..., p. 424.

${ }^{135}$ FeRnández Ramos: El derecho de acceso..., p. 425.

${ }^{136}$ FeRnÁdez Ramos: El derecho de acceso..., p. 424. En tal sentido se ha pronunciado también el Tribunal Supremo, que ha considerado que el derecho de acceso no se extiende a la solicitud de entrega de certificados sobre datos no elaborados. Señalando que «el recurrente no pretende el acceso a los registros y archivos municipales, sino que se le expida una certificación sobre datos no elaborados, lo que implica mantener que si no lo ha hecho con anterioridad la Administración está obligada a realizar la elaboración correspondiente para atender a las peticiones de los ciudadanos». STS de 2 de junio de 2000. RCJ 2000-6733. FJ. 2.
}

${ }^{137}$ FERnÁNDEZ Ramos: El derecho de acceso..., p. 425. 
tivos que impidieran que dichas circunstancias se produzcan ${ }^{138}$. Pues lo contrario supone dotar a la Administración de la facultad de denegar el acceso a la documentación cuyo conocimiento le resulte inconveniente destruyéndolos o «dejándolos» que se pierdan. Está, además, fuera de toda duda, que la simple desidia o negligencia en la custodia de los documentos no puede suponer el recorte de un derecho de los ciudadanos ${ }^{139}$.

Uno de los aspectos de la regulación del derecho de acceso que ha generado una mayor polémica es, indudablemente, la exigencia impuesta por el art. 37. 1 LPC de que se trate de expedientes que «correspondan a procedimientos terminados en la fecha de solicitud» (art. 37. 1 LPC). Lo que excluye la aplicación de este derecho a los documentos que formen parte de expedientes aún no concluidos.

Aunque la valoración de esta limitación no ha sido totalmente uniforme, la mayor parte de la doctrina ha dado sobre la misma un juicio negativo. Si bien con diferente intensidad, pues algunos la tildan de inconstituciona ${ }^{140}$, mientras que otros, de forma más matizada, la consideran tan sólo inadecuada o injustificada, pues entienden que debería establecerse

\footnotetext{
138 Como señala SAINZ MoRENO, «dado que la mayor parte de la información de los entes públicos está incorporada a documentos y que, por tanto, sólo puede accederse a ella en la medida en que estos documentos se conserven, es muy importante regular con precisión el deber de conservar y de incorporar a los archivos y registros esa documentación». Secreto y..., p. 169.

${ }^{139}$ Como señala DE OCAÑA LACAL, «la existencia del documentos ha de ser presupuesto previo para el ejercicio del derecho. El problema surge cuando el documento ha desaparecido y a nadie le importa mucho cómo, cuándo ni por qué ni, desde luego, se intentan dilucidar responsabilidades». Ignorancia, ilegalidad y otros..., p. 198, nota 69.

140 Considera Parada VÁzqueZ que se «trata ciertamente de una amputación de un derecho constitucionalmente protegido, no sólo porque el art. 105 no opera esa distinción entre expedientes terminados y no terminados, sino también en función de su obligada interpretación extensiva por una relación íntima con "el derecho a recibir libremente información veraz por cualquier medio de difusión" que proclama el art. 20 de la Constitución». «Ningún sentido tiene, pues, que en una Ley sobre Régimen Jurídico y el Procedimiento Administrativo Común dictada para regular la actividad de los procedimientos vivos no terminados, acabe reglamentando el acceso a los ya terminados, a los difuntos y enterrados, dejando sin regular lo primero que es el objeto precisamente de la Ley». Régimen Jurídico de las..., p. 156. En la misma línea VAQUER CABALLERÍA, que considera que esta exclusión «carece desde luego de justificación y es, en consecuencia, inconstitucional por violación del art. 105. b CE. Ciertamente que no siempre procederá el acceso a la información relativa a los procedimientos inconclusos: su denegación puede hallar fundamento jurídico cuando tutele la intimidad de los interesados en el procedimiento (art. $18 \mathrm{CE}$ ) o pueda poner en peligro la eficaz terminación del procedimiento de que se trate o de los intereses generales a que éste sirva (art. 103. $1 \mathrm{CE}$ ), por ejemplo, pero ello sólo se producirá eventualmente, no necesariamente. Son, en efecto, supuestos circunstanciales, por lo que ya están previstos en el art. 37 LRJPAC como causa de denegación del acceso allí donde concurran, y por lo mismo no pueden en ningún caso justificar una exclusión general y abstracta en la ley». Derechos de los ciudadanos..., p. 92. También en este sentido, ÁLVAReZ Rico y Álvarez Rico: Derecho de acceso a los..., p. 487.
} 
esta limitación únicamente para los expedientes en curso en los que existan razones que así lo justifiquen (eficacia de la Administración, derecho a la intimidad, etc. $)^{141}$. Hay también, por último, quien ha defendido la constitucionalidad de la opción tomada por la $\mathrm{LPC}^{142}$.

A nosotros nos parece que no hay ningún interés constitucionalmente protegido que justifique una restricción absoluta del acceso a los expedientes que estén en tramitación. Por ello, consideramos que dicha limitación no está justificada y que constituye, en consecuencia, una vulneración de un derecho constitucional por parte del legislador ordinario. Todo ello sin perjuicio de que en determinados supuestos esa limitación pueda ser legítima, por encontrar apoyo en un interés jurídico de entidad constitucional y, por tanto, con aptitud para limitar un derecho constitucionalmente protegido como lo es el derecho de acceso.

En cualquier caso, dado que la regulación actual sigue manteniendo esa estipulación, a pesar de su más que dudosa constitucionalidad, debemos precisar cuales son las consecuencias que se derivan de la misma.

En primer lugar, entendemos que no es preciso, para que se considere el procedimiento terminado a estos efectos, que se trate de documentos relativos a actos totalmente ejecutados ${ }^{143}$, ni tampoco que se trate de documentos relativos a actos firmes ${ }^{144}$.

Lo que supone que bastaría con que se haya dictado acto definitivo en el procedimiento, para poder acceder a los documentos que obren en su expediente. Esto excluye del acceso los documentos que constituyan o reflejen actos de trámite hasta que se produzca la conclusión del procedi-

\footnotetext{
141 Fernández Ramos: El derecho de acceso..., pp. 439-444. La misma opinión SÁnChez Morón, que considera que «no está justificado que el procedimiento en que el documento se integra deba estar ya terminado en su totalidad cuando la información se solicita, pues no siempre el acceso por terceros a un documento perjudica el buen fin de la instrucción, reserva esta última que sí sería lógica, en cambio, la necesidad de esperar a la terminación del procedimiento podría mermar la utilidad del ejercicio del derecho de acceso». El derecho de acceso..., p. 40.

142 Pomed SÁnchez: El acceso a los, ... p. 457. Embid Irujo, en El ciudadano y la ..., p. 106. También Villanueva Cuevas, que considera que «la publicidad de los documentos durante la tramitación del procedimiento puede producir perjuicios a los verdaderos interesados en el mismo, por lo que no resulta, a nuestro juicio, excesivamente incorrecto que, en aras de proteger al verdadero afectado por el procedimiento, se limite al derecho de acceso a la conclusión de éste». El derecho de..., p. 118.

143 Fernández Ramos: El derecho de acceso..., p. 445. Konnickx Frasquet, en La Ley Básica de..., pp. 1214-1215.

144 FeRnÁndez Ramos: El derecho de acceso..., pp. 445-446. Pomed SÁnChez: El acceso a los..., p. 462. KonnickX Frasquet, en La Ley Básica de..., p. 1214.
} 
miento principal ${ }^{145}$. Sin que sea admisible la consideración de los dictámenes e informes como actos terminales de un procedimiento, pues deben ser considerados a estos efectos actos de trámite ${ }^{146}$.

La interposición de un recurso o la iniciación de un procedimiento de revisión de oficio contra ese acto definitivo, supone la incoación de un nuevo procedimiento, por lo que no debe impedir ejercitar el acceso respecto a los documentos derivados del procedimiento en que se dictó la resolución objeto de revisión ${ }^{147}$.

A la terminación del procedimiento mediante resolución o acto definitivo se debe equiparar los demás supuestos de terminación previstos en el art. 87 LPC (desistimiento, renuncia, caducidad e imposibilidad material de la terminación del procedimiento) ${ }^{148}$, la terminación convencional prevista en el art. $88 \mathrm{LPC}^{149}$, y la finalización del procedimiento por silencio administrativo $^{150}$.

Por último, debe también señalarse que esta exigencia no puede impedir el acceso a los documentos que no formen parte de un expediente, pues, lógicamente, para éstos nunca se va a producir la terminación del mismo, con lo que quedarían excluidos del derecho de acceso ${ }^{151}$.

El tercer paso para determinar el contenido de este derecho, será precisar las concretas facultades en que se traduce lo que genéricamente denominamos como acceso.

La primera facultad que lo integra es, lógicamente, la de tomar conocimiento directo de los documentos de que se trate. Como señala el Tribunal Supremo, el acceso «implica examinar presencialmente y tomar cono-

\footnotetext{
145 GutiÉRrez Delgado: Régimen Jurídico de..., p. 239.

146 GutiÉRrez DELGADo considera que «no cabe entender, pues sería evidentemente contrario al espíritu del art. 37. 1 de la LRJ-PAC, que el procedimiento administrativo concluye con la emisión del dictamen, y, por consiguiente, que éste podría ser conocido inmediatamente por cualquier interesado ajeno a la Administración». Régimen Jurídico de..., p. 239.

147 Konnickx Frasquet, en La Ley Básica de..., p. 1214. Chaves García: La información ciudadana..., p. 160.

148 KonNickX Frasquet, en La Ley Básica de..., p. 1214.

149 Fernández Ramos: El derecho de acceso..., p. 444.

150 SANTAMARÍA PASTOR: Comentario sistemático a la ..., p. 143. Fernández RAMOs: El derecho de acceso..., p. 444. Pomed SÁNCHEZ: El acceso a los..., p. 462. EMBID IRUJo, en El ciudadano y la..., pp. 106-107. KonNickx Frasquet, en La Ley Básica de..., p. 1214.

151 Fernández Ramos: El derecho de acceso..., pp. 442-443.
} 
cimiento personal de sus contenidos» ${ }^{152}$. La forma en que se va a llevar a la práctica esta facultad la estudiaremos con detalle más tarde, cuando analicemos el modo de ejercicio del derecho.

También conlleva el derecho a obtener copias o certificados de los documentos cuyo examen sea autorizado por la Administración, previo pago, en su caso, de las exacciones que se hallen legalmente establecidas (art. 37. 8 LPC). A lo que añade un sector de la doctrina la posibilidad de solicitar, cuando sea posible, esa copia en formato informático ${ }^{153}$; la de requerir que esa copia sea compulsada, si se debe presentar en un organismo público que así lo exige, y queda dicho extremo debidamente justificado ${ }^{154}$; e incluso que el administrado pueda pedir que se le remitan esas copias a la dirección que solicite, siempre, lógicamente, que se hiciera cargo de los costes que ello genere ${ }^{155}$.

Esta facultad no puede dar lugar, sin embargo, a peticiones abusivas, que puedan suponer un perjuicio para el eficaz funcionamiento de la Administración ${ }^{156}$.

Cuando se trate de documentos que afecten a la intimidad de las personas, éstas podrán exigir, en el supuesto de observar que tales datos figuran incompletos o inexactos, que sean rectificados o completados, salvo que figuren en expedientes caducados por el transcurso del tiempo, conforme a los plazos máximos que determinen los diferentes procedimientos, de los que no pueda derivarse efecto sustantivo alguno (art. 37. 2 LPC).

\section{LÍMITES}

En realidad, el análisis de los límites del derecho de acceso no es una cuestión nueva en este estudio. Como el lector habrá seguramente observa-

\footnotetext{
152 STS de 25 de octubre de 2002. RCJ 2002-10209. FJ. 2.

153 FeRnÁndez Ramos: El derecho de acceso..., p. 548.

154 Konnickx Frasquet, en La Ley Básica de..., p. 1234.

${ }^{155}$ FERnÁndez Ramos: El derecho de acceso..., p. 549.

156 En tal sentido, la REDACCIÓN DE «EL CONSUltor DE LOS AyUnTAMIENTOS» señala que el derecho a obtener copias no puede convertirse en un derecho indiscriminado a la obtención de copias y certificaciones. Pues, que esto «pueda suponer una limitación indirecta al derecho a la obtención de copias y certificaciones es cierto, pero tampoco es concebible una Administración que debe reproducir en multiplicidad de copias todas sus actuaciones para tenerlas a disposición de quien las pueda pedir». Nuevo Régimen Local. Cuarta edición. Madrid, 2001, p. 1180.
} 
do, al fijar el objeto de este derecho hemos estudiado ya algunas restricciones importantes al mismo. Tampoco se puede decir que en este apartado vayamos a analizar los restantes limites a los que está sujeta esta facultad, pues, la remisión a materias específicas o el modo de ejercicio del derecho conllevan también la exclusión del acceso a determinados documentos.

Esperemos que nos sea perdonada esta descoordinación, de la que ciertamente no nos sentimos responsables. Pues, la inclusión en un mismo epígrafe de todos los límites que pesan sobre el derecho de acceso en la regulación contenida en la LPC, supondría prácticamente reducir todo este estudio a un único apartado: el que examine los límites del derecho.

Y es que el legislador básico puede que no haya estado especialmente inspirado en el desarrollo del art. $105 \mathrm{CE}$, que, como hemos visto en varias ocasiones, es francamente deficiente en muchos aspectos; pero, sin embargo, ha demostrado una gran habilidad para limitar el derecho, pues ciertamente es difícil introducir tantas limitaciones en tan mínimo espacio. Muy poco verdaderamente ha escapado al afán reduccionista del autor de la LPC, pues en el texto del art. 37 LPC se pueden encontrar limitaciones al definir el derecho, al regular su objeto, al fijar el modo en que lleva a cabo su ejercicio, al fijar los supuestos sometidos a normativa específica y, como no, al regular los límites, tanto los específicos como los genéricos, pues de ambos tipos hay.

Por esta razón, hemos decidido estudiar en este apartado únicamente los límites que se presentan expresamente como tales, analizando en su lugar propio otros que se le añaden al tratar otras cuestiones.

Por ello, sin perjuicio de esas otras limitaciones que se examinan en otros apartados de este trabajo, vamos a distinguir entre las restricciones que se establecen a nuestro derecho entre las específicas, que regula el 37.5 LPC, que vienen referidas a supuestos determinados, y las genéricas, que fija el art. 37. 4 LPC, que no vienen referidas a una materia específica y determinada. Vamos a comenzar con estas últimas, en virtud de las cuales se puede denegar el ejercicio del derecho de acceso cuando prevalezcan:

\section{a) Razones de interés público}

Algunos autores dan por buena esta restricción ${ }^{157}$. Sin embargo, en nuestra opinión, no es posible aceptarla con carácter general. Pues este

157 Embid Irujo, en El ciudadano y la..., p. 122. KonnickX Frasquet, en La Ley Básica de..., p. 1226. 
tipo de intereses tendrán una eficacia prevalente al derecho de acceso sólo si cuentan con una cobertura constitucional que deba imponerse a nuestro derecho. Debiendo, en caso contrario, ceder ante la facultad objeto de este estudio $^{158}$.

\section{b) Intereses de terceros más dignos de protección}

Nos encontramos con una situación similar a la examinada previamente, pues dada la cobertura constitucional del derecho de acceso, los intereses de terceros sólo serán más dignos de protección que éste, cuando cuenten con un apoyo constitucional que deba imponerse al interés protegido por el art. $105 \mathrm{CE}^{159}$.

En ambos supuestos (razones de interés público, intereses más dignos de protección), el problema que se plantea es el mismo. No es que sea criticable la excepción que se fija, pues ambos factores pueden ser aptos en determinados casos para restringir el derecho de acceso, sino su excesiva indeterminación, incompatible con una correcta garantía del derecho de acceso $^{160}$. No debe, por ello, bastar con el simple hecho de invocar un interés público o de un tercero para que quede justificada una excepción, sino que debe someterse al juicio de proporcionalidad al que antes hemos hecho referencia, para verificar si esos intereses tienen relevancia constitucional suficiente para limitar nuestro derecho.

Sin que se pueda enervar lo dicho, como sugieren algunos autores, por la consideración de esos intereses como conceptos jurídicos indeterminados ${ }^{161}$. Pues la razón de la indeterminación no proviene propiamente de que no se pueda precisar si un determinado objetivo constituye un interés público o de un tercero. Sino de que eso no nos dice absolutamente nada acerca de la validez de la excepción. Pues el simple hecho de que exista interés público o de tercero no implica que éste tenga que prevalecer sobre

\footnotetext{
158 SANTAMARÍA PAStOR: Comentario sistemático a la..., p. 144. De OCAÑA LACAL: Ignorancia, ilegalidad y otros..., p. 184, nota 29. Villanueva Cuevas: El derecho de acceso..., pp. 125-126.

159 Santamaría Pastor: Comentario sistemático a la..., p. 144. De OCAÑA LACAL: Ignorancia, ilegalidad y otros..., p. 184, nota 29. VILLANUEVA CUEVAS: El derecho de acceso..., pp. 125-126.

160 SÁnchez Morón: El derecho de acceso..., p. 40. Fernández Ramos: El derecho de acceso..., pp. 485-487. De OCAÑa LACAL: Ignorancia, ilegalidad y otros..., p. 184.

161 Embid IrUjo, que señala, en referencia a la excepción por existencia de un interés público, que «la naturaleza del interés público es la del concepto jurídico indeterminado pero susceptible de determinación y, por tanto, la imposibilidad de que su cita se convierta en una apelación que pueda conducir a una situación real de discrecionalidad». En El ciudadano y la..., p. 122.
} 
el derecho de acceso. Sólo lo hará si conforme a un juicio de proporcionalidad, en los términos vistos, queda debidamente justificada esa restricción.

\section{c) Cuando así lo disponga una Ley}

También en este caso algunos autores han defendido la legitimidad de esta limitación, desde la consideración de que se trata de un derecho de configuración legal ${ }^{162}$. Sin embargo, a nosotros no nos parece admisible que la mera voluntad del legislador sea suficiente para dar amparo a una restricción de un derecho constitucionalmente reconocido, como lo es el derecho de acceso. Los limites que eventualmente puedan fijar las normas de rango legal serán válidas o no dependiendo únicamente de la consistencia de su fundamentación. De tal forma que sólo cuando queden suficientemente justificados por otros bienes o derechos constitucionalmente protegidos serán legítimos ${ }^{163}$.

$\mathrm{El}$ art. 37. 4 LPC establece que para denegar el acceso por alguna de estas tres causas es necesario que el órgano competente dicte resolución motivada. Una medida aparentemente garantista, que en realidad tiene un carácter restrictivo, pues, como veremos posteriormente con mayor detalle, toda denegación del derecho de acceso es un acto que limita derechos subjetivos, que debe ser, en consecuencia motivado (art. 54. 1. a LPC), tal y como se establece en el ámbito local en los art. 70. 3 LBRL y art. 207 ROF.

En cuanto a las limitaciones específicas, están recogidas en el art. 37.5 LPC, según el cuál, no cabe ejercitar el derecho de acceso respecto a los siguientes expedientes:

a) Los que contengan información sobre las actuaciones del Gobierno del Estado o de las Comunidades Autónomas, en el ejercicio de sus competencias constitucionales no sujetas a Derecho administrativo (art. 37. 5 LPC).

Esta limitación hace referencia a las actuaciones del ejecutivo estatal y autonómico que constituyen lo que tradicionalmente se han venido desig-

\footnotetext{
162 Así, EmBiD Irujo, que considera esta restricción lógica, en cuanto estamos «ante un derecho de configuración legal. No obstante, habrá de adoptarse siempre la precaución de no conferir a la Ley capacidad de vaciar, por su mera forma de Ley, el contenido constitucionalmente garantizado del derecho». En El ciudadano y la..., p. 122, nota 54. KonNickX FRASQUET, en La Ley Básica de..., op. 1226.

163 SAnTAMARÍA PASTOR: Comentario sistemático a la..., p. 144. Fernández Ramos: El derecho de acceso..., p. 485.
} 
nando como actos políticos ${ }^{164}$. Dado que comprende tanto la actividad política del gobierno estatal como del autonómico, debería haberse hablado no sólo de competencias «constitucionales», sino de competencias constitucionales y estatutarias ${ }^{165}$. A lo que añaden algunos autores que se debería haber incluido una referencia a los actos políticos de las Entidades Locales ${ }^{166}$. Si bien otros justifican esta última omisión por el escaso volumen de actividades puramente políticas en este ámbito ${ }^{167}$.

Algunos autores encuentran su justificación en que no se trata de un supuesto de acceso a la documentación administrativa, sino a la documentación generada por la actividad de carácter político, y, por tanto, no administrativa, de los órganos que desarrollan las funciones ejecutivas ${ }^{168}$. No compartimos esta opinión, pues el criterio que delimita el acceso no es tanto el régimen jurídico al que está sujeta la información documentada (administrativo, político, privado), como la titularidad de los documen$\operatorname{tos}^{169}$.

Parece, por ello, más adecuada la postura que encuentra la razón de ser de esta excepción en el principio de eficacia, considerando que dicho fundamento no otorga una cobertura para toda la información que proceda de actos políticos, sino sólo para aquella cuya divulgación pudiera disminuir la eficacia de la actuación de que se trate ${ }^{170}$.

\footnotetext{
164 Mestre Delgado El derecho de acceso a..., p. 144. Fernández Ramos: El derecho de acceso... p. 459.

165 Konnickx Frasquet, en La Ley Básica de..., p. 1224. Villanueva Cuvas: El derecho de acceso..., p. 121.

166 Villanueva Cuevas, que considera que «estas actuaciones no administrativas son posibles, por lo que tal deficiencia aparece como un olvido relevante de la LAP, originada, quizá, por el carácter claramente restrictivo que desde sus orígenes presentaba esta exclusión, y que no concordaba $-\mathrm{y}$ sigue sin hacerlo respecto a la Administración Local- con el reconocimiento de la autonomía a las Comunidades Autónomas y de la autonomía local a los Entes Locales que realiza la Constitución Española». El derecho de acceso..., p. 121.
}

167 EmBid Irujo, según el cuál, «que no se incluya a los entes locales puede tener también una explicación, sino de lógica jurídica, sí de comprensión sobre la real actividad de pura política de estos entes y, por lo tanto, de la extensión cubierta -más que pobre- de la exclusión del derecho de acceso respecto a los expedientes relacionados con la misma». El ciudadano y..., p. 120.

168 Embid Irujo, en La nueva ley de..., pp. 115-116. Mestre Delgado: El derecho de acceso a..., p. 144. Villanueva Cuevas: El derecho de acceso..., p. 120.

169 Fernández Ramos: El derecho de acceso..., pp. 461-462.

170 Para SANTAMARÍA PASTOR estas limitaciones «pueden hallar un título legitimador en el principio constitucional de eficacia; un título que, sin embargo, no cubre la totalidad de tales informaciones (que naturalmente, pueden ser de relevancia muy diversa), sino sólo aquéllas cuya divulgación a través del ejercicio de este derecho pudiera disminuir o eliminar la operatividad de las decisiones líci- 
b) Los que contengan información sobre la Defensa Nacional o la Seguridad del Estado (art. 37. 5 LPC).

La justificación de este límite parece indiscutible ${ }^{171}$, si bien esta exclusión no tiene porque extenderse a toda la actividad que afecte a la defensa y seguridad del Estado, sino tan sólo a aquella parte de la misma cuya divulgación pueda afectar negativamente a tales bienes ${ }^{172}$.

El ámbito material de aplicación de esta excepción coincide con el régimen especial de acceso reconocido respecto a las materias clasificadas. Por ello, un sector de la doctrina ha defendido que se deben integrar ambos supuestos, aplicando la excepción tan sólo cuando se trate de materias previamente clasificadas ${ }^{173}$. Sin embargo, en nuestra opinión, debe entenderse que son dos supuestos distintos, residiendo la diferencia entre uno y otro en que haya mediado previamente o no acto formal de clasificación de una actividad como secreta o reservada ${ }^{174}$. Debe tenerse en cuenta que, cuando se trate de materias ya clasificadas, el órgano administrativo al que se le solicite el acceso, comprobada dicha circunstancia, podrá denegar éste; mientras que, si la materia no está ya clasificada, debería de carecer de la facultad de denegar el acceso por sí mismo, debiendo remitir la cuestión al órgano competente para llevar a cabo la clasificación de esos documentos, que será al que le corresponda tomar la decisión ${ }^{175}$.

tamente adoptadas por el ejecutivo». Comentario sistemático a la..., p. 142. FernÁNDEZ RAMOS: El derecho de acceso..., p. 463. La misma opinión DE OCAÑA LACAL, que considera la redacción de este precepto «muy deficiente, excluyendo del mismo a todo expediente en el que, en mayor o menor medida, se aluda a un acto político, sin tener en cuenta ni la materia ni si su conocimiento enturbiaría o no el proceso decisorio». Ignorancia, ilegalidad y otros..., pp. 188-189.

171 Mestre Delgado: El derecho de acceso a..., p. 127.

172 Fernández Ramos: El derecho de acceso..., pp. 474-475. VillanueVA Cuevas: El derecho de acceso..., p. 122.

173 VillanUEVA CuEvas, que considera «que se debería realizar una refundición de ambos preceptos de la LAP e interpretar que sólo las materias que afecten a la defensa y seguridad del Estado que hayan sido clasificadas serán excluidas del derecho de acceso. El derecho de acceso..., pp. 122-123.

174 Fernández RAmos, que señala que «la función del apartado 5 b) del art. 37 no es otra que excluir del derecho de acceso a documentos que, aun cuando no hayan sido objeto de clasificación formal, sean merecedores de ella por su potencialidad para comprometer la seguridad del Estado, pues carecería de sentido negar tal protección por el mero hecho de que a la fecha de la petición del documento no hubiere recaído el acto formal de clasificación. Se trata, por tanto, de una vía complementaria a la técnica preventiva de materias clasificadas» El derecho de acceso..., pp. $475-476$.

175 FERnÁndez Ramos: El derecho de acceso..., pp. 476-477. 
c) El art. 37. 5 LPC excluye los tramitados para la investigación de los delitos cuando: a) pudiera ponerse en peligro la protección de los derechos y libertades de terceros; b) pudiera ponerse en peligro las necesidades de las investigaciones que se estén realizando. Si bien, en el último supuesto citado, debería entenderse esta exclusión limitada al periodo de tiempo en el que se desarrolla esa investigación ${ }^{176}$. No parece cuestionable esta excepción, que acoge el propio art. 105. b CE, y que parece plenamente adecuada, dada la gravedad que puede derivarse de la divulgación de la información a la que viene referida ${ }^{177}$.

d) Los relativos a las materias protegidas por el secreto industrial o comercial (art. 37. 5 LPC).

Esta excepción no tiene por objeto la protección de secretos del Estado o la Administración, sino que se establece a favor de cualesquiera sujetos que realicen una actividad empresarial ${ }^{178}$. Sin perjuicio de que sirva también al objetivo de salvaguardar la confianza en las relaciones entre Administración y administrado. En cuanto resultaría, de no reconocerse esta excepción, extremadamente difícil obtener de los agentes económicos la información de este tipo que los entes públicos requieran para el ejercicio de sus funciones ${ }^{179}$.

Por ello, consideramos, pese a que algunos autores justifican esta limitación basándose en que se trata de una extensión natural del ámbito de la intimidad $^{180}$, que la postura más correcta es la de considerar que encuentra su fundamento en la libertad de empresa ${ }^{181}$.

e) Los relativos a actuaciones administrativas derivadas de la política monetaria (art. 37. 5 LPC).

Para algunos esta excepción está plenamente justificada, en cuanto se trata de un supuesto específico de acto político, por lo que su exclusión se

\footnotetext{
176 Mestre Delgado: El derecho de acceso a..., pp. 136.

177 La misma opinión, Villanueva Cuevas: El derecho de acceso..., p. 124.

178 Señala FERNÁNDEZ RAMOS que «la cláusula del secreto comercial o industrial no tiene por objeto proteger secretos de Estado o de la Administración, sino de los particulares (...), y ello sin perjuicio de que cuando la Administración actúa como empresario, a través de sociedades mercantiles en régimen de mercado o libre competencia, pueda beneficiarse también de esta cláusula de secreto comercial o industrial». El derecho de acceso..., p. 518.

179 FERnÁNDEZ RAmos: El derecho de acceso..., pp. 521-522.

180 SANTAMARÍA PAStor: Comentario sistemático a la..., p. 142.

181 FernÁndez Ramos: El derecho de acceso..., p. 520. Embid Irujo, en El ciudadano y la..., p. 121, nota 53. KonNickx Frasquet, en La Ley Básica de..., p. 1225.
} 
fundamenta, como la de los demás actos políticos, en no constituir documentación administrativa, sino documentación relativa a actuaciones políticas $^{182}$. Entendemos, sin embargo, que su justificación reside en el principio de eficacia. Lo que implica que sólo será legítima en la medida que el acceso a esa información pudiera disminuir dicha eficacia ${ }^{183}$.

\section{MODO DE EJERCICIO}

La LPC comienza el tratamiento de esta materia advirtiendo que, el ejercicio del derecho de acceso, debe ser ejercitado por los particulares de forma que no se vea afectada la eficacia del funcionamiento de los servicios públicos (art. 37. 7 LPC). Previsión que en el ámbito local recoge el art. 230. 2 ROF, que advierte que las gestiones a las que de lugar el ejercicio de nuestro derecho no pueden suponer «entorpecimiento de las tareas de los servicios municipales». No se puede decir que sea una cautela excesivamente justificada, pues dado que sólo se permite el acceso a los expedientes terminados, la consulta sólo se puede realizar en los archivos, y éstos tiene como finalidad precisamente permitir el acceso a los documentos, por lo que mal se puede perjudicar su funcionamiento ${ }^{184}$. En cualquier caso, dicha estipulación permite a la Administración rechazar peticiones abusivas, que por su volumen o por otro motivo, puedan distorsionar gravemente el funcionamiento del archivo, registro o servicio del que se trate ${ }^{185}$.

El ejercicio del derecho va a dar lugar a la tramitación de un procedimiento administrativo, que carece, salvo algunas referencias puntuales, de

\footnotetext{
182 Mestre Delgado: El derecho de acceso a..., p. 158. EmBid IRujo, en El ciudadano y la... p. 121, nota 53 .

183 Para SANTAMARÍA PASTOR esta limitación puede «hallar un título legitimador en el principio constitucional de eficacia; un título que, sin embargo, no cubre la totalidad de tales informaciones (que naturalmente, pueden ser de relevancia muy diversa), sino sólo aquéllas cuya divulgación a través del ejercicio de este derecho pudieran disminuir o eliminar la operatividad de las decisiones lícitamente adoptadas por el ejecutivo». Comentario sistemático a la..., p. 142. Fernández Ramos: El derecho de acceso..., p. 482. Villanueva Cuevas: El derecho de acceso..., pp. 124-125.

184 SANTAMaría PASTOR: Comentario sistemático a la..., p. 145. De acuerdo con ello, DE OCAÑA LACAL, que califica, por ello, este precepto como un «monumento al cinismo». Ignorancia, ilegalidad y otros..., pp. 200-201. También FERNÁNDEZ RAMOs, que considera que a los ciudadanos les puede parecer un sarcasmo. El derecho de acceso..., p. 533.

185 KonNickX Frasquet, en La Ley Básica de..., p. 1235. En tal sentido, el art. 2 OAACMP permite rechazar aquellas peticiones que «por el excesivo número de los documentos solicitados, hagan imposible o muy difícil el cumplimiento por los servicios del departamento de los actos de instrucción establecidos» en dicha norma.
} 
una regulación específica en la $\mathrm{LPC}^{186}$, lo que nos obligara a recurrir frecuentemente a las normas generales de procedimiento para fijar su régimen jurídico.

Dada su naturaleza, este procedimiento será de los que se inicien siempre a instancia de parte, mediante la presentación de una solicitud.

Entendemos, aunque hay quien ha defendido postura contraria ${ }^{187}$, que dicha solicitud no deberá contener en principio justificación alguna de los motivos por los que se solicita al acceso, dado que se trata de un derecho cuyo ejercicio en principio no requiere legitimación. Sin perjuicio de que ésta sea exigible en los supuestos en que haya que demostrar que se está legitimado ${ }^{188}$.

En el ámbito local, sin embargo, el art. 230 ROF establece lo contrario, pues exige que las «peticiones de información deberán ser razonadas, salvo que se refieran a la obtención de certificaciones de acuerdos o resoluciones». Aunque hay un sector de la doctrina que ha valorado favorablemente dicho precepto ${ }^{189}$, entendemos que dicha precisión carece de validez respecto al derecho de acceso, salvo en los supuestos en los que sea exigible legitimación. Pues forma parte del contenido esencial de este derecho que el acceso se produzca al margen de todo requisito de legitimación y, por tanto, sin que pueda ser exigida justificación alguna. Como hemos visto, en algunos casos se imponen limitaciones a nuestro derecho, de las que se derivan la exigencia de legitimación. Esto permite que en casos puntuales, para justificar esa legitimación, se pueda obligar a hacer expresos los motivos por los que se solicita el acceso. Pero fuera de estos casos, la Administración carece de capacidad no sólo para cuestionar, sino incluso para indagar, las razones que llevan al administrado a ejercitar este derecho.

El requisito más importante que debe cumplir la solicitud es la identificación de los documentos que se desean consultar, pues la Ley establece que se deberá formular petición individualizada de los mismos (art. 37. 7 LPC). No siendo posible formular solicitud genérica sobre una materia o conjunto de materias, salvo para su consideración potestativa (art. 37. 7 LPC $)^{190}$.

\footnotetext{
186 Factor que ha sido muy criticado por la doctrina. FERNÁNDEZ RAMOS: El derecho de acceso..., p. 526.

187 KonNICKX Frasquet, que considera que será exigible motivación, «salvo en los casos de acceso libre o que solicite un documento el propio titular del mismo». En La Ley Básica de..., p. 1231.

188 FERNÁNDEZ RAMOS: El derecho de acceso..., pp. 529-530.

189 Konnickx Frasquet, en La Ley Básica de..., p. 1231.

190 El Tribunal Supremo ha considerado compatible con el principio de transparencia, que se niegue el acceso cuando se formula «una petición injustificadamente genérica u opaca». Siendo, por
} 
Esta restricción es admisible si no se aplica con excesivo rigor, pero sería inadecuado si se traduce en la exigencia de una identificación exacta de los documentos ${ }^{191}$. Por ello, debe desecharse la opinión, sostenida por algunos autores, que consideran que la Administración carece de obligación alguna respecto a las peticiones genéricas ${ }^{192}$. Debiéndose interpretar que la facultad de consideración potestativa de este tipo de peticiones, no otorga una absoluta discrecionalidad a la Administración para denegar o no el acceso, sino tan sólo la mera posibilidad de rechazar éste, cuando se demuestre que de concederse el mismo se entorpecería el correcto funcionamiento del servicio ${ }^{193}$. A tales efectos, entendemos que se deben considerar suficientemente individualizadas las peticiones que identifiquen el expediente en que se encuentre el documento ${ }^{194}$, aunque algunos autores piensen lo contrario ${ }^{195}$.

La necesidad de que se formule petición individualizada se extiende también al derecho a realizar copias. Como señala el Tribunal Supremo, el art. «37.8 no establece un derecho a la obtención indiscriminada de copias o certificados de documentos por los particulares, ya que según el apartado 7 del precepto el derecho de acceso se ejercitará debiéndose formular petición "individualizada" de los documentos que se desee consultar, sin que quepa,

tanto, posible rechazar el acceso cuando se formule la «petición de forma absolutamente genérica, sin concretar en un grado mínimamente razonable el tipo o características de los documentos o datos que interesan». STS de 14 de noviembre de 2000. RCJ 2001-425. FJ. 5. En dicha resolución se formuló, no obstante, voto particular, que mantenía parecer contrario al aquí reseñado, por J. A. Xiol Ríos.

191 Pomed SÁnchez: El acceso a los..., p. 463. SÁnchez Morón: El derecho de acceso..., p. 40. KonNickX Frasquet, en La Ley Básica de..., pp. 1231-1232. Señala Santamaría Pastor que la «exigencia es razonable siempre que no se interprete con rigor, por cuanto una identificación exacta, completa y sin errores de los documentos administrativos es imposible: salvo que haya precedido alguna confidencia interna dudosamente legítima, ningún ciudadano suele poseer la información suficiente como para efectuar una petición inequívoca y carente de cualquier elemento genérico». Comentario sistemático a la..., p. 145.

192 Garcés Sanagustín, en Derecho administrativo especial. P. 292.

193 Mestre Delgado: El derecho de acceso a..., p. 173, nota 67. FernándeZ Ramos: El derecho de acceso..., p. 536. En esta línea se sitúa el art. 2 OAACMP, que fija como criterio para denegar el acceso por esta causa que «las peticiones (...) por su falta de concreción (...) hagan imposible o muy difícil el cumplimiento por los servicios del departamento de los actos de instrucción establecidos» en dicha norma.

194 Fernández Ramos: El derecho de acceso..., p. 536. Konnickx Frasquet, en La Ley Básica de..., p. 1232.

195 Así, Chaves García, según el cuál, «parece que debemos deducir que la petición tiene que concretar un documento y no un expediente, pues de lo contrario, el precepto debería decir algo así como «los ciudadanos tienen derecho a acceder a los expedientes que obren en los archivos administrativos». La información ciudadana...,p. 166. 
salvo para su consideración con carácter potestativo, formular solicitud "genérica" sobre una materia o conjunto de materias; limitación que lógicamente se extiende al derecho a obtener copias o certificados de los documentos a que alude el apartado 8 del citado art. $37 \gg^{196}$.

No se exigen, en principio, requisitos especiales de forma, por lo que podrá ser presentada, como cualquier otra solicitud, utilizando medios informáticos o telemáticos ${ }^{197}$. Sería, no obstante, conveniente, hacer constar en la solicitud la modalidad de acceso que se desea (directo, a través de copia, certificación $)^{198}$.

En principio, salvo que la conservación del documento u otras razones lo aconsejen (por ejemplo si sólo se puede dar acceso parcial), se debe permitir la consulta del propio documento, no la simple entrega de una copia $^{199}$. Parece evidente que la Administración esta facultada para imponer que esa consulta se sujete a determinados condiciones: que se desarrolle en un lugar determinado, en un horario concreto, siempre que no sea excesivamente restrictivo, o imponer la presencia de un agente público durante la misma ${ }^{200}$. Si al administrado lo considera oportuno para la defensa de sus derechos, debería permitírsele que acceda a los documentos acompañado de un asesor ${ }^{201}$.

Se puede autorizar, cuando los solicitantes sean investigadores que acrediten un interés histórico, científico o cultural relevante, el acceso directo de aquéllos a la consulta de los expedientes». Debiendo entenderse que este acceso directo supone la posibilidad de acceder a los archivos o documentos sin la mediación de los funcionarios que estén a su cargo ${ }^{202}$. Si bien, siempre será necesaria una cierta vigilancia, para que, como exige el art. 37. 7 LPC, «quede garantizada debidamente la intimidad de las personas». E igualmente «para asegurar el mantenimiento del orden en y entre los expedientes $»^{203}$.

\footnotetext{
196 STS de 14 de marzo de 2000. RCJ 2000-3182. FJ. 3. En el mismo sentido, STS de 13 de febrero de 1998. RCJ 1998-2185. FJ. 4. STS de 29 de abril de 1998. RCJ 1998-4574. FJ. 5.

197 FERnÁNDEZ RAmos: El derecho de acceso..., p. 528.

198 FERnÁndez RAmos: El derecho de acceso..., p. 530.

199 FERNÁNDEZ RAmos: El derecho de acceso..., pp. 545-547.

200 FERnÁndez Ramos: El derecho de acceso..., p. 547.

201 FERnÁndez Ramos: El derecho de acceso..., p. 549.

202 Da Silva OchoA, en Administraciones Públicas y..., p. 327.

203 Da Silva Ochoa, en Administraciones Públicas y..., p. 327, nota 54. Fernández Ramos: El derecho de acceso..., p. 526.
} 
Es criticable que se haya diferenciado entre los investigadores y los demás ciudadanos ${ }^{204}$, pues debe darse por superada en el momento actual la consideración de los archivos como un ámbito excluido del gran público y restringido a una elite minoritaria ${ }^{205}$. A lo que añaden algunos, que la posibilidad de acceso directo debería haberse extendido también al periodismo de investigación, que consideran tan importante como la investigación académica ${ }^{206}$.

Pero quizá el mayor error de esta estipulación sea el modo en que se ha llevado a cabo, pues carece, como en muchos otros aspectos del derecho de acceso, de la necesaria densidad normativa, provocando el indeseable defecto de dotar al órgano encargado de su aplicación de un margen excesivo de discrecionalidad ${ }^{207}$.

A la hora de decidir sobre la concesión o no del acceso directo parece adecuado, en cualquier caso, que se ponga el énfasis no en el elemento subjetivo, esto es, si la persona merece o no la consideración de investigador; sino en el aspecto objetivo, esto es, en el interés de la investigación ${ }^{208}$.

El acceso debe ser gratuito salvo en lo que se refiere a la posibilidad de obtener copias o certificaciones, en cuyo caso se podrá hacer recaer sobre el administrado el gasto que supone su realización ${ }^{209}$.

El plazo para resolver sobre la petición, al no establecerse nada al respecto, es el subsidiario de 3 meses (art. 42. 3 LPC). Si bien se tiende a considerar que ese plazo es demasiado amplio y la doctrina solicita que se

\footnotetext{
204 DE OCAÑA LACAL señala que «la norma parece escorarse hacia la más pura -y rancia- tradición propia de tiempos preconstitucionales, de establecer categorías de ciudadanos al diferenciar entre los investigadores y el resto». Ignorancia, ilegalidad y otros..., p. 179.

${ }^{205}$ Como señala Alonso IBÁÑEZ, existe «el convencimiento de que hay que superar la vieja idea de que son simples depósitos de materiales o centros de investigación reservados a una minoría. Por el contrario, deben entenderse como un núcleo de proyección cultural y social, con una continua y decisiva función didáctica». El patrimonio histórico..., p. 178.

206 Parada VÁzquez: Régimen Jurídico de las..., pp. 158-159.

207 Señala De OCAÑa LaCal que esta limitación se establece «sin que se sepa cómo, quién o qué determina dicha relevancia. De nuevo acecha el peligro de la arbitrariedad, encontrando en ciertos casos una sospechosa sinonimia entre la relevancia y simple recomendación o enchufe». Ignorancia, ilegalidad y otros..., p. 180.

${ }^{208}$ Fernández Ramos: El derecho de acceso..., p. 527. Konnickx Frasquet, en La Ley Básica de..., p. 1233.

209 Mestre Delgado: El derecho de acceso a..., p. 173. Fernández Ramos: El derecho de acceso..., pp. 551-552.
} 
establezca uno menor ${ }^{210}$. En todo caso, parece exigible que, como impone en el ámbito local el art. 230. 2 ROF, se de satisfacción a la solicitud «en el plazo más breve posible».

No se señala el sentido del silencio para el caso de que transcurra dicho plazo sin que se dicte resolución o se notifique ésta, lo que en aplicación de las normas que regulan el silencio administrativo determina que éste tendrá sentido positivo (art. 43. 2 LPC). Salvo que se establezca por la normativa especifica que el silencio tendrá sentido negativo, siempre que esa normativa específica sea una norma con rango de ley o una disposición de Derecho comunitario (art. 43. 2 LPC).

Una parte de la doctrina ha señalado que el silencio será negativo cuando «se trate de expedientes respecto a los cuales no es ejercitable el derecho de acceso por ministerio de la ley» ${ }^{211}$. Esta postura no es, a nuestro entender, correcta. Dado que, en nuestro ordenamiento jurídico, se producen los efectos del silencio, incluso aunque la persona que se beneficia del acto presunto carezca de los requisitos esenciales para ello.

Ello no impide que dicho acto presunto incurra en una causa de nulidad de pleno derecho (concretamente la del art. 62. 1. f LPC, que sanciona con el grado máximo de invalidez los «actos expresos o presuntos contrarios al ordenamiento jurídico por los que se adquieren facultades o derechos cuando se carezca de los requisitos esenciales para su adquisición»). Pero esa sanción sólo se puede hacer valer a través de un recurso o mediante un procedimiento de revisión de oficio, pues el art. 43. 4 LPC impide en su letra a) dictar resolución expresa posterior contraria a la estimación por silencio.

En tales supuestos, puede que la concesión del acceso produzca un daño al interés privado o público tutelado por la excepción que impide el acceso. Por lo que en el procedimiento de impugnación del acto se debe solicitar la suspensión de la ejecución, que debería concederse, pues la consulta de los documentos ocasionaría en caso contrario un perjuicio irreparable (con base en el art. 104 LPC en caso de revisión de oficio y en el 111 LPC en caso de recurso). El acuerdo que denegase la suspensión en dicho caso sería recurrible de forma separada, por ser un acto de trámite cualificado en cuanto produce un perjuicio irreparable (art. 107. 1 LPC).

210 Embid Irujo, en La nueva ley de..., p. 119. Fernández Ramos: El derecho de acceso..., pp. 542543. Villanueva Cuevas: El derecho de acceso..., p. 130.

211 Garcés Sanagustín, en Derecho administrativo especial. p. 292. 
Algunos han señalado que el silencio administrativo no parece un arma excesivamente eficaz para proteger al administrado frente a una eventual inactividad de la Administración respecto a una petición de acceso, pues el ciudadano lo que pretende es una conducta activa de la Administración, lo que determina que el silencio le aporte muy poco si ésta se resiste a cumplir el acto presunto $^{212}$. Sin embargo, no se debe olvidar que ese silencio positivo le abre la puerta para emprender, tras formular el oportuno requerimiento a la Administración, la tutela judicial por inactividad de la Administración (art. 29 LJ).

La resolución que conceda el acceso debería fijar un plazo máximo para proceder a la consulta, transcurrido el cual se perdería el derecho a llevarla a cabo, debiéndose solicitar para acceder a los documentos una nueva solicitud. Si bien deberá exigirse una amplitud mínima a ese plazo, para evitar que sea excesivamente breve, convirtiéndose en una vía para restringir el acceso $^{213}$.

\section{SUPUESTOS ESPECIALES}

El acceso a algunos expedientes se rige, según el art. 37. 6 LPC, por sus normas específicas: a) el acceso a los archivos sometidos a la normativa sobre materias clasificadas; $b$ ) el acceso a documentos y expedientes que contengan datos sanitarios personales de los pacientes; c) los archivos regulados por la legislación del régimen electoral; d) los archivos que sirvan a fines exclusivamente estadísticos dentro del ámbito de la función estadística pública; e) el Registro Civil y el Registro Central de Penados y Rebeldes y los registros de carácter público cuyo uso esté regulado por una ley; f) el acceso a los documentos obrantes en los archivos de las Administraciones Públicas por parte de las personas que ostenten la condición de Diputado de las Cortes Generales, Senador, miembro de una Asamblea legislativa de la Comunidad Autónoma o de una Corporación Local; g) la consulta de fondos documentales existentes en los Archivos Históricos ${ }^{214}$.

\footnotetext{
212 FeRNÁNDEZ RAmos: El derecho de acceso..., pp. 557-559.

${ }^{213}$ FERnÁndeZ RAmos: El derecho de acceso..., p. 548.

214 Véase, Ley 9/1968, de 5 de abril, regula los secretos oficiales. Resolución de la Presidencia del Congreso de los Diputados de 2 de junio de 1992, sobre acceso a secretos oficiales. BOCG, Serie E, n. ${ }^{\circ} 208$, de 3 de junio. Ley Orgánica 3/1981, de 6 de abril, Defensor del Pueblo. Ley 14/1986, de 25 de abril, General de Sanidad. Ley 41/2002, de 14 de noviembre, Reguladora de la Autonomía del Paciente y de Derechos y Obligaciones en Materia de Información y Documentación Clínica. Ley Orgánica 5/1985, de 19 de junio, Régimen Electoral General. Ley 12/1989, de 9 de mayo, de la Función Estadística Publica. Resolución de 24 de febrero de 1982, de la Presidencia del Congreso de los Diputados, ordena la publicación del Reglamento del Congreso de los Diputados. Ley
} 
Merece la pena destacar, por su incidencia en el ámbito local, el supuesto contemplado en la letra $\mathrm{f}$ ), que concede un régimen privilegiado de acceso a favor de determinados sujetos, entre los que se encuentran los miembros de las Corporaciones Locales, como manifestación del art. 23 $\mathrm{CE}^{215}$. Dicho régimen aparece recogido en la $\mathrm{LBRL}^{216} \mathrm{y}$ en el $\mathrm{ROF}^{217}$.

de 8 de julio de 1957, regula el Registro Civil. Ley 16/1985, de 25 de junio, que regula el Patrimonio Histórico Nacional. Sobre el Registro Central de Penados y Rebeldes véase STC 144/1999, de 22 de julio de 1999. FJ. 8.

215 Konnick Frasquet, en La Ley Básica de..., pp. 1228-1229. Villanuevas Cuevas: El derecho de acceso..., p. 128.

${ }^{216}$ Concretamente en su art. 77, que establece que todos «los miembros de las Corporaciones locales tienen derecho a obtener del Alcalde o Presidente o de la Comisión de Gobierno cuantos antecedentes, datos o informaciones obren en poder de los servicios de la Corporación y resulten precisos para el desarrollo de su función». «La solicitud de ejercicio del derecho recogido en el párrafo anterior habrá de ser resuelta motivadamente en los cinco días naturales siguientes a aquel en que se hubiesen presentado».

${ }^{217}$ Concretamente en sus art. 14 a 16.

«Todos los miembros de las Corporaciones Locales tienen derecho a obtener del Alcalde o Presidente o de la Comisión de Gobierno cuantos antecedentes, datos o informaciones obren en poder de los servicios de la Corporación y resulten precisos para el desarrollo de su función» (art. 14. 1 ROF).

«La petición de acceso a las informaciones se entenderá concedida por silencio administrativo en caso de que el Presidente o la comisión de gobierno no dicten resolución o acuerdo denegatorio en el término de cinco días, a contar desde la fecha de la solicitud» (art. 14. 2 ROF).

«En todo caso, la denegación del acceso a la documentación informativa habrá de hacerse a través de resolución o acuerdo motivado» (art. 14. 3 ROF).

«No obstante lo dispuesto en el número 1 del artículo anterior, los servicios administrativos locales estarán obligados a facilitar la información, sin necesidad de que el miembro de la Corporación acredite estar autorizado, en los siguientes casos:

a) Cuando se trate del acceso de los miembros de la Corporación que ostenten delegaciones o responsabilidades de gestión, a la información propia de las mismas.

b) Cuando se trate del acceso de cualquier miembro de la Corporación, a la información y documentación correspondiente a los asuntos que hayan de ser tratados por los órganos colegiados de que formen parte, así como de las resoluciones o acuerdos adoptados por cualquier órgano municipal.

c) Cuando se trate del acceso de los miembros de la Corporación a la información o documentación de la entidad local que sean de libre acceso para los ciudadanos» (art. 15 ROF).

«La consulta y examen concreto de los expedientes, libros y documentación en general se regirá por las siguientes normas:

a) La consulta general de cualquier expediente o antecedentes documentales podrá realizarse, bien en el archivo general o en la dependencia donde se encuentre, bien mediante la entrega de los mismos o de copia al miembro de la Corporación interesado para que pueda examinarlos en el despacho o salas reservadas a los miembros de la Corporación. El libramiento de copias se limitará a los casos citados de acceso libre de los concejales a la información y a los casos en que ello sea expresamente autorizado por el Presidente de la Comisión de Gobierno. 


\section{TUTELA}

El acto de denegación del derecho de acceso debe ser, aunque la LPC no lo establece, motivado en todo caso, por aplicación del art. 54. 1. a) LPC, según el cual serán motivados los «actos que limiten derechos subjetivos o intereses legítimos» ${ }^{218}$. Tal y como exige en el ámbito local el art. 70. 3 LBRL, según el cuál, la «denegación o limitación de este derecho (...) deberá verificarse mediante resolución motivada».

Lo que supone que la motivación debe ser precisa no sólo cuando se produzca una denegación total del acceso, sino también cuando tenga lugar un rechazo parcial, pues supone igualmente la restricción de un derecho $^{219}$.

Esta exigencia pesa igualmente sobre los actos que, por permitir el acceso, puedan ser restrictivos de derechos de terceros interesados, por ejemplo, vulneración de derecho a la intimidad, secreto comercial, etc. ${ }^{220}$

La resolución denegatoria del acceso es «un acto administrativo o resolución de tal carácter, dictada por órgano administrativo competente, y cuya vía de impugnación ante la denegación que supone es la vía

b) En ningún caso los expedientes, libros o documentación podrán salir de la Casa Consistorial o Palacio Provincial, o de las correspondientes dependencias y oficinas locales.

c) La consulta de los libros de actas y los libros de resoluciones del Presidente deberá efectuarse en el archivo o en la Secretaría General.

d) El examen de expedientes sometidos a sesión podrá hacerse únicamente en el lugar en que se encuentren de manifiesto a partir de la convocatoria» (art. 16. 1 ROF).

«En el supuesto de entrega previsto en el apartado a) del número anterior, y a efectos del oportuno control administrativo, el interesado deberá firmar un acuerdo de recibo y tendrá la obligación de devolver el expediente o documentación en un término máximo de cuarenta y ocho horas, o antes, en función de las necesidades del trámite del expediente en cuestión» (art. 16. 2 ROF).

«Los miembros de la Corporación tienen el deber de guardar reserva en relación con las informaciones que se le faciliten para hacer posible el desarrollo de su función, singularmente de las que han de servir de antecedente para decisiones que aún se encuentran pendientes de adopción, así como para evitar la reproducción de la documentación que pueda serles facilitada, en original o copia, para su estudio» (art. 16. 3 ROF).

218 Embid Irujo, en La nueva ley de..., p. 119. Fernández RAmos: El derecho de acceso...,p. 555. SÁNCHEZ Morón: El derecho de acceso..., p. 40.

219 FERnÁNDez Ramos: El derecho de acceso..., p. 555. Así lo exige el art. 21. a de la Ley de 19 de abril de 1991, normas reguladoras de Archivos y Patrimonio Documental de Castilla y León, que establece que la denegación o limitación del derecho de acceso deberá «producirse motivadamente y por escrito».

220 FERnÁNDEZ RAmos: El derecho de acceso..., pp. 555-556. 
administrativa y en su caso la de la jurisdicción contencioso-administrativa» ${ }^{221}$.

Al ser un simple derecho subjetivo, no fundamental, es tan sólo susceptible de tutela ante los tribunales ordinarios ${ }^{222}$. No siendo posible invocar su protección a través del procedimiento preferente y sumario ante los Tribunales ordinarios que prevé el art. 53. 2 CE o del recurso de amparo $^{223}$. Así lo ha confirmado el Tribunal Constitucional, que ha establecido que «las reglas y principios contenidas en los artículos (...) 105 b) (...) de la Constitución son inadecuadas para fundamentar una petición de amparo en cuanto que en ninguno de ellos se reconocen derechos fundamentales y libertades políticas de los incluidos como amparables en el artículo 53. 2 de la Constitución» ${ }^{224}$.

Ahora bien, la adecuación del recurso contencioso-administrativo para dar tutela a este derecho es más que cuestionable, dada la tardanza habitual en la resolución de este tipo de procesos ${ }^{225}$.

Algunos autores proponen, por ello, la creación de un órgano que revista la forma de una Administración independiente, para conocer en vía administrativa de los recursos contra los actos que resuelvan sobre el acceso. Si bien entienden que ese órgano debería de carecer de facultades decisorias, de tal forma que sus resoluciones no tuvieran carácter vinculante para la Administración ${ }^{226}$. Hay una parte de la doctrina que cuestiona esta solución ${ }^{227}$.

En el recurso contencioso el Juez deberá poder acceder no sólo al expediente a que haya dado lugar la petición de acceso, sino también al expediente respecto al cual se solicita éste. Si bien, lógicamente, dicha posibilidad

\footnotetext{
${ }^{221}$ SAP de Navarra de 29 de junio de 1995. AC 1995-1243.

${ }^{222}$ Da Silva OchOA, en Administraciones Públicas y..., p. 327. EmBID IruJo, en La nueva ley de..., pp. 114-115. Mestre Delgado: El derecho de acceso a..., p. 174.

${ }^{223}$ EmbiD Irujo, en La nueva ley de..., pp. 104 y 120.

${ }^{224}$ STC 161/1988, de 20 de septiembre de 1988. FJ. 4.

225 Mestre Delgado: El derecho de acceso a..., p. 175. Sánchez Morón: El derecho de acceso..., p. 41.

226 Mestre Delgado: El derecho de acceso a..., p. 184. Fernández Ramos: El derecho de acceso..., pp. 563-567.

227 Así, EmBID IRujo considera que «conviene ser parco en las propuestas de creación de nuevos organismos administrativos que en ocasiones, sí, vienen a solucionar problemas de organización pero que en otras, simplemente, los crean por la combinación de la estructura burocrática producida». En El ciudadano y la..., p. 125, nota 64.
} 
de acceso no se extenderá a las partes, pues es precisamente el acceso por parte de uno de los litigantes lo que se discute en el procedimiento ${ }^{228}$. Una vez consultado el documento, el juez deberá elaborar un acta en la que, sin revelar el contenido del mismo, de noticia a la contraparte del resultado de dicho examen 229 .

Sin embargo, esta solución no será aplicable a los supuestos en que la razón para denegar el acceso sea la perturbación que supone para el funcionamiento del servicio. Pues no parece que sea necesario consultar el documento para decidir sobre tal extremo. A lo que se añade que eso obligaría a localizar el documento o documentos, lo que implicaría necesariamente que se produjera esa perturbación.

El acto que permita el acceso, cuando debería haberse negado éste, puede dañar derechos o intereses legítimos de otras personas (intimidad, secreto comercial... ), pudiendo dar lugar a responsabilidad patrimonial de la Administración si genera daños a los administrados ${ }^{230}$. Ese acto será, además, susceptible de suspensión en cuanto produce un perjuicio irreparable (art. 111 LPC) ${ }^{231}$. En caso de que esa suspensión no se concediera, se podrá impugnar de forma separada el acuerdo en que se rechace la misma, pues es un acto de trámite susceptible de producir perjuicio irreparable (art. 107 LPC).

\footnotetext{
228 Mestre Delgado: El derecho de acceso a..., p. 188. FernÁndez Ramos: El derecho de acceso..., pp. 572-574.

229 FERnÁNDEZ RAmos: El derecho de acceso..., p. 574.

230 FERnÁNDEZ RAmos: El derecho de acceso..., p. 542.

231 FERnÁNDEZ RAmos: El derecho de acceso... pp. 571-572.
} 